\title{
Geleneksel Kazak Kültüründeki Koç Kültüyle İlgili Etnoarkeolojik Incelemeler
}

\author{
Tattigül Kartaeva* - Yerdan Oralbay**
}

\section{$\ddot{O ̈}_{z}$}

Kazak ve diğer Türk soylu halkların dünya görüşünde koç oldukça önemli bir kült hayvanı olarak kabul edilmiş̧ir. Eski Kazak mezar taşlarına (koytas, koşkartas) çeşitli koyun/koç tasvirlerinin işlenmiş olması bu uygulamanın arkeolojik kazılarda ortaya çıkan kilden yapılmış koç figürleri ve kaya resimlerindeki (petroglif) çeşitli koyun/ koç resimlerinde görülen geleneğe bağlandığını ve bu kültün köklerinin çok eski devirlere dayandığını ortaya koymaktadır. Antik çağlara ait kap kulplarının hayvan biçimli veya özellikle koyun/koçbaşı şeklinde biçimlendirildiği görülmektedir. Koyun/ koç ile ilgili kültler, Eskiçağ'da Saka ve Kangli, Ortaçağ'da ise Oğuz ve Kıpçak boylarının yaşamlarında önemli yer tutmuştur. Koçun insanın ruhani düşüncesiyle ve yaşamının dönüşüm anlarıyla ilgili kutsal bir bağa sahip olduğu düşünülmektedir. Halk arasındaki efsane ve inançlara göre koç, gök ve ateşten yaratılmıştır. Bu inanç, birçok eski doğu halkları arasında İslamiyet öncesinde yaygın olan doğa tapınışı ile ilgilidir. Türk soylu halkların inancına göre koyun/koç, koruyucu özelliğinin yanı sıra kutsallara kurban edilebilecek kutsal bir hayvan niteliğindedir. Kazaklar ve Türk soylu halklar arasında evcil hayvanlara ait bazı kemiklerin mucizevî özelliklere sahip olduğu şeklinde, ilginç gelenekler, batıl inançlar ve efsaneler yaygındır. Koyun/koç boynuzu (koşkarmüyüz) şeklindeki süslemenin bu halklar için bereketi ve zenginliği sembolize ettiği anlaşılmaktadır.

Anahtar Kelimeler: Koç kültü, dünya görüşü, hayvan totemi, boynuz şeklindeki (koşkarmüyüz) süslemeler.

* Prof. Dr., Al-Farabi Kazak Millî Üniversitesi, Tarih, Arkeoloji ve Etnoloji Fakültesi, Arkeoloji, Etnoloji ve Müzecilik Bölümü, Almatı/KAZAKİSTAN, kartaeva07@gmail.com ORCID: 0000-0001-6180-4107 DOI: 10.37879/belleten.2020.907

** Kıdemli Araştırmacı, Al-Farabi Kazak Millî Üniversitesi, Tarih, Arkeoloji ve Etnoloji Fakültesi, Arkeoloji, Etnoloji ve Müzecilik Bölümü, Almatı/KAZAKISTAN, oralbai79@mail.ru ORCID: 0000-0003-4976-8929

Makale Gönderim Tarihi: 02.09.2015 - Makale Kabul Tarihi: 11.08.2020 


\title{
Ethnoarchaeological Approach to the Cult of Ram in Traditional Kazakh Culture
}

\begin{abstract}
The cult of the sheep/ram plays an important role in the life and ethos of the Kazakhs and many Turkic tribes as a totem animal. Numerous sculptural images of the ram depicted in the old Kazakh tombstones (qoitas, qoshqartas) and clay ram figurines were found in archeological excavations. The ram images in the rock engravings (petroglyphs) indicate its roots related to the ancient religions. Some of the handles in ancient pottery were zoomorphic in shape, and especially in the form of ram head. The cult of sheep/ram was connected with the specific conditions of life, traditions, husbandry of ancient tribes as Sakha, Kangli, and Medieval Oghuz and Kipchak. The cultic significance of the sheep/ram is explained by its sacredness related to the idea of human soul, and to moments of transformation. This cult has close connection with the tradition of nature worship in the pre-Islamic people of the ancient East. The sheep/ram served not only as a sacrificial animal, but also a talisman for Turkic people. There were interesting Kazakh and Turkic customs, superstitions and legends connected with the miraculous peculiarities of some bones of domestic animals. The images of the sheep/ram in the form of a horn (qoshqarmuyiz) symbolize wealth and fertility.
\end{abstract}

Keywords: The cult of ram, worldview, totem of an animal, ornament in the form of horn (qoshqarmuyiz).

\section{Giriş}

Kazak halkının totem anlayışında kurttan sonra dört tür hayvan (tülük: deve, at, koyun, sığır gibi hayvanların genel adı) önemli bir yere sahiptir. Genel olarak hayvanlar hakkındaki anlayış ile inanç ve öğretiler, avcı-toplayıcı Paleolitk Çă̆ yaşamında kalıplaşmış, göçebe hayvancılık döneminde ise daha çok gelişme göstermiştir. Eski dönemlerde bazı yırtıcı hayvanlar silahsız insanlar için bir tehdit unsuru iken, sakin ve otçul hayvanlar besin ve diğer ihtiyaçlar açısından kaynak olmuştur. Kemik, boynuz, diş ve derileride günlük hayatı kolaylaştıran malzemeler haline dönüştürülebildiği için, vahşi ya da uysal tüm hayvanlar kutsal varlıklar olarak görülmeye başlanmıştır. Öncelikle yırtıcı hayvanlardan zarar gelmemesi, daha sonra da uysal hayvanlardan daha çok faydalanabilmek için hayvanların kutsal sayıldıkları anlaşılmaktadır. Maddi kültür kalıntılarının yanında halk yaşamindaki sözlü edebiyat ürünlerinde, gelenek, görenek ve inançlarda hayvanlara karşı duyulan, korku ve saygı kendini göstermektedir. Türk soylu halklar da çok 
eski dönemlerden itibaren dört grup evcil hayvan (tülük) ile vahşi hayvan ve kuşları kutsal saymıştır.

Çalışma multidsipliner bir araştırma olup etnoloji ve arkeoloji biliminin ortaklaşa kullanılmıştır. Araştırmada açık hava müzelerindeki koç şekilli taşlar ve kaya resimlerindeki oyma koç şekilleri esas alınmıştır. Tarihi materyal içerisinde yer alan bu tür malzemeler üzerinde yapılan incelemelerle Kazak halkının toplumsal hayatında koçun rolü, yeri ve öneminin aydınlatılması amaçlanmıştır. ${ }^{1}$

Yerli arkeologlar Karl Baypakov, Zeynolla Samaşev, jeoarkeologlar Renato Sala, Jean-Mark Deom, etnograflar Serik Ajiğali, Halel Arğınbayev, Nursan Alimbay’ın² yazıları, arkeoloji ve etnoloji bilim dalının disiplinler arası bağlantılarınıanaliz etmek için bir ön koşul haline gelmiştir.

Koyun / koç bilgisi Türk halklarının yaşam destek sistemindeönemli bir yere sahiptir. Proto-Kazakların koyun ve koç bilgisinin Türk halklarıyla ortaklı̆̆ı, Ertuğrul Danık, Yaşar Kalafat, Mustafa Aksoy, Ali Rıza Özdemir. Yaşar Çoruhlu, Tuncer Gülensoy, Yunus Berkli gibi bilim adamları tarafindan yapılan arkeoetnografik araştırmalarda ele alınmıştır. ${ }^{3}$

1 Yazarın arkeo-etnografik araştırma materyalleri, makalenin ana bilimsel kaynağını oluşturmaktadır: Mangıstau, Donıztau, Üstürt, Sır Derya seferleri - 2014-2018;

2 Renato Sala - Jan-Mark Deom, Naskalniye izobrajeniye Yezhnogo Kazakhistana, Geoarkheologiya Almaty 2005; Zeynolla Samaşev - Krymbek Kuşerbaev - Ermek Amanşaev - Andrei Astaf'ev, Sokrovisha Usturta i Mangistau, Arheologiya, Almaty 2007; Karl Baypakov, "Kul't barana u syrdar'inskih plemen". V knige: Arheologicheskie issledovaniya drevnego i srednevekovogo Kazahstana, Gylym, Almaty 1980, s.32-34.; Serik Ajiğali, Kratel elinin asyl murasy: koshpendi Aral-Kaspii onirinin tarihy men madenieti turaly. Almaty: Timas Printhause. 2006; Nursan Alimbay, vd., Kazaktyn etnografyalyk kategorizalar, ugymdar men ataularymyn destrrli zhuiesi. 3 tom. Almaty: Adam DamuIntegrasiya, 2017; Halel Arğinbayev, "Narodnye obichai i pover'ya kazahov, sviazannye so skotovodstvom". $V$ knige: Hoziaistvenno-kul'turnye tradicii narodov Srednei Azii i Kazahstana, Nauka, Moskva 1975, s.194-205.

3 Ertuğrul Danık, Koç ve At Şeklindeki Tunceli Mezar Taşlan, Ankara 1990; Ertuğrul Danık, "Koç ve at şeklindeki Anadolu mesar taşlarinin dağilimi”, Turk Arkeoloji ve Etnografya Dergisi, 4 (2004): s. 19-28. http://www.kulturvarliklari.gov.tr/sempozyum_pdf/dergi/turk.ark.etn.derg.4.pdf (Erişim Tarihi: 30.11. 2016); Yaşar Kalafat, Kars'ta Gregoryen Türkler Ve Mezar Mimarileri - Ak Ve Kara Koyunlu Mezar Taşlarinin Çizdiği Tarihî-Coğrafi Kültürün Sinirlari Ihttp://www.yasarkalafat. info/kalafat.info/dosyalar/kalafat2014151920.pdf (Erişim Tarihi: 27.11.2016); Mustafa Aksoy, Tunceli'de Koç-Koyun Heykelleri ve Balballar $\backslash$ http://www.mustafaaksoy.com/makale-114-Tunceli-de-Koc-Koyun-Heykelleri-ve-Balballar (Erişim Tarihi: 30.11.2016); Kazakistan'da Koç - Koyun Heykelli Mezar Tasslan \http://www.mustafaaksoy.com/dosyalar/Kazakistan-da-Koc-KoyunHeykelli-Mezarlar.pdf (Erişim Tarihi: 29.11.2016); Ali Rıza, Özdemir. Koģ Heykelli Mezarlarn İzinde: Zazalar Ve Türklïk, Kripto Yayınları, Ankara 2010.; Yaşar Çoruhlu, "Türk Sanatı'nda Koyun, Koç, Keçi Figürlerinin Sembolizmi”, Türk Dünyası Tarih Dergisi, 100 (Nisan 1995): s. 5260; Yaşar Çoruhlu, "At ve Koç/Koyun Şekilli Mezar Taşlarının Sembolizmi”, Toplumsal Tarih, 94 
Yazılı verileri yazarın keşif materyalleriyle vesomut verilerle teyyit etmesi, bu çalışmanın orijinalliğini ortaya koymaktadır.

\section{Açık Hava Müzelerindeki Taşlarda ve Kaya Oymalarındaki Koç Şekilleri}

Kazak topraklarındaki Arpaözen, Sauskandık (Karatau), Hantau, Kuljabası, Tanbalı (Çu-İli Dağları), Eşkiölmes, Bayanjürek (Congar Aladağı) kaya oymalarında günümüzde soyu tükenmiş olan boynuzlu yaban domuzu, aslan, kaplanın bazı türleriyle birlikte pars, geyik, dağ keçisi, dağ oğlağı, yaban domuzu, at, yabani eşek, ceylan, kurt, deve, boğa, koç, koyun, keçi, yılan, kuşlar, köpek figürleri ve mitolojik hayvanlar taşlara yontmatekniğiyleişlenmiştir.Bu anıtlar, çok eski dönemlerde yaşayan halkların yaşam biçimleriyle bağlantı kurmamızı sağlayan aradaki paha biçilmez miraslardır. Adı geçen kaya oymalardaki koyun, koç arketipi 3000 sene evvelki dönemden bugüne kadarki Kazak halkının kültürel yaşamıyla zihniyetinde önemli simgesel bir rol oynadığını göstermektedir.

Bayanjürek dağından doğuya doğru 20 km. yerde Tasbas kompleksindeki kültürel peyzaj alanında yaklaşık Tunç Çă̆ı'nın sonu ile Erken Demir Çağı sonuna ait olduğu sanılan (M.Ö. I. binyılın ilk yarısı) granit üzerine oyularak tasarlanmış koyunun taştan yapılmış heykelleri saklanmıştır (Resim - 1-3). ${ }^{4}$ Taş höyükün birindeki taş paravana koç boynuzu şekli verilmiştir. ${ }^{5}$ Tasbas'taki dev koyun taşlar (koç şekli verilmiş taşlar) kaya oymaların yüksek kabartma (fr. Haut-relief), proto-anıtlar, jeoglif (geoglyph) gibi çok nadir türlerinden sayılmaktadır ve onlar doğal bir şekilde oluşan granitlerin üzerine yontulan eski ustaların toplu çalışmalarının neticesinde ortaya konulmuştur.

(2000), s. 35-42; Tuncer Gülensoy, Orhun'dan Anadolu’ya Türk Damgalar, İstanbul 1989. s. 26-32; Yunus Berkli. "Erzurum'da Yeni Bulunan Haç Motifli Koç Heykelinin Düşündürdükleri". A.Ü. Türkiyat Araştrmalan Enstitiusü Dergisi, 34 (2007), s. 215-232.

4 Renato Sala - Jan-Mark Deom, age., s. 53-55,137.

5 Renato Sala - Jan-Mark Deom, age, s. 139 


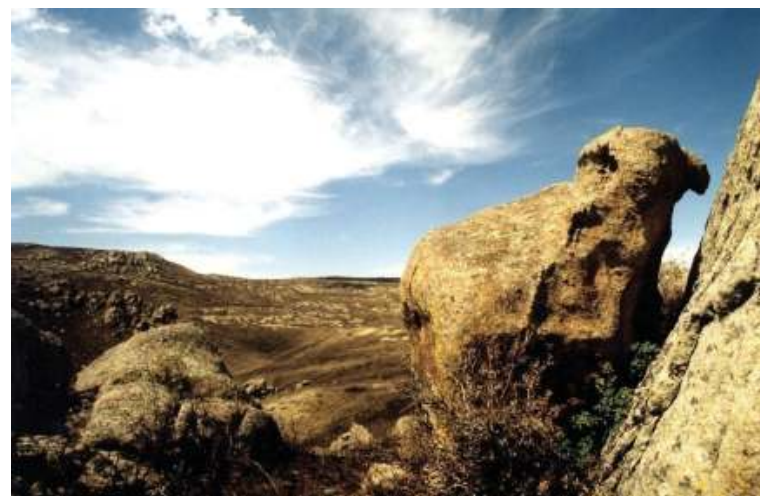

Resim 1: Tasbas'taki koyun taş (koç şeklindeki taş).

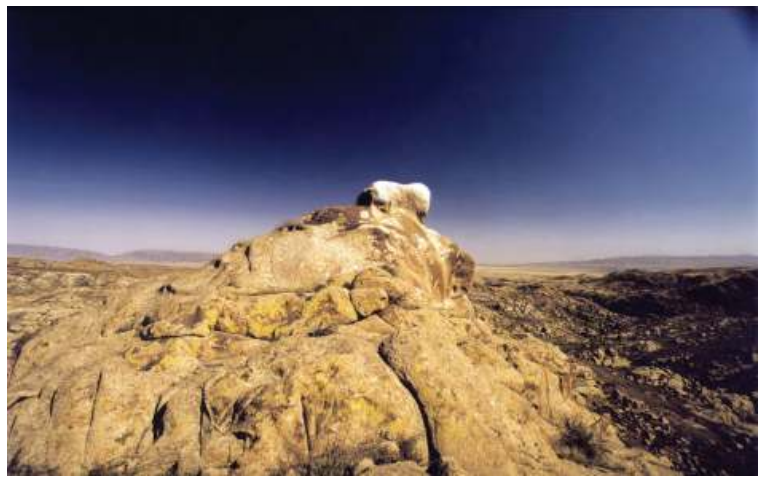

Resim 2: Tasbas'taki koyun taş (koç şeklindeki taş).

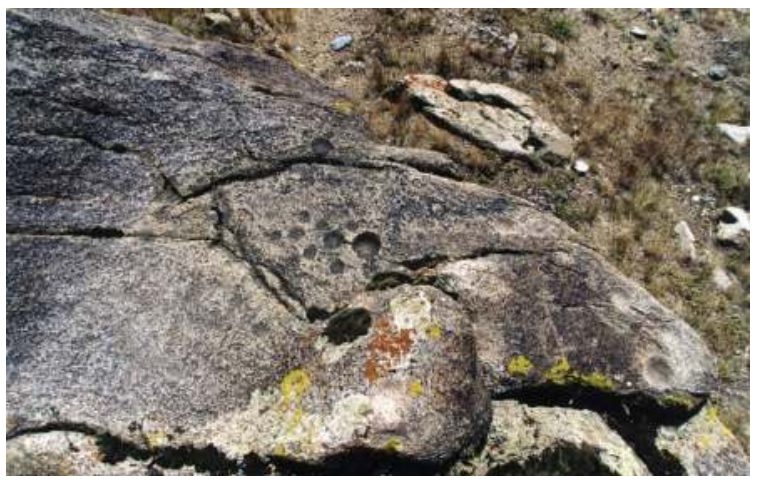

Resim 3: Tasbas’taki koyun taş (koç şeklindeki taş). 
Özbekistan'daki Orta Tunç Çağı'na ait olduğu öne sürülen Sarımışsay kaya oymalarındaki koç başlı mitolojik insan figürünün baş kısmı güneş yuvarlağı gibi sembolize edilmişken, başından yukarıya doğruuzanan iki anteni Gök Tanrı'ya ulaştıran ve bağlayan bir yol gibidir (Resim 4).

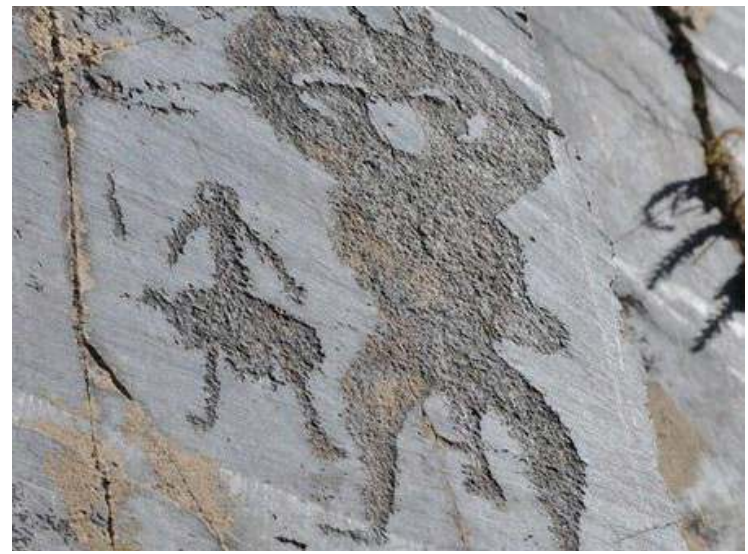

Resim 4: Sarımışsay'daki koç başlı adam. Özbekistan.

Ancak Tunç ve Demir Çağı kaya oymalarında ise koç şekilleri değil, dağkoyunu, dağ keçisi figürleri daha fazladır. Bazen dağ keçisi ile koç figürlerini ayırt etmek epey zordur. Mesela, süt keçisinin boynuzunun kıvrılmış şekli, dağ keçisini de andırır. ${ }^{6}$

\section{Erken Dönemlerdeki Türk Soylu Kabilelerin Dünya Görüşünde Koyun ve Koç Kültü}

Demir Çağı'nın sakinleri olan Saka kabilelerinin dini kült anıtları ile Sır Derya'nın eski kanalı İnkar Derya boyundaki Uyğarak yerleşim bölgeleri ile Jetiasar (Yediaşar) medeniyetinden kalma anıtlar, eski kabilelerin koyun, koç kültüyle ilgili birçok verilere sahiptir. Sır Derya nehrinin aşağı akışı boyunda M.Ö. 7 - 5 asra ait olduğu sanılan Saka ve Massaget kabilesi yerleşim bölgeleri ile kalelerinin büyük bir bölümü bulunmaktadır. Saka ve Massaget'lilerin siyasi ve idari merkezi Şirik - Rabat ile Babiş mezarlığının Sır Derya'nın aşağı akışı boyunda yerleştiğine dikkat edersek, Saka kurganlarının buralarda pek fazla olması şaşırtıcı değildir. Sır bölgesindeki Saka kurganlarının tipik özellikleri içinde, insan naaşıyla birlikte

6 Renato Sala -Jan-Mark Deom, age., s. 139-147.

Belleten, Aralık 2020, Cilt: 84/Sayı: 301; 907-958 
koyun kemiklerini de birlikte gömmek vardır. Mesela, №16. kurganda kuyumşak (sağrı kemikleri, omurganın alt ucunun bitim yeri, kuyruk sokumu olan kısım), No35. Kurganda 241 aşı kemiği, No36. kurganda omurga ile 5 aşık kemiği, Nơ4. kurganda 2 aşık kemiği, No57. kurganda koyun kellesi gömülüdür.7

Koyun kemiklerinin insan naaşıyla birlikte gömülü olduğu mezarlıklar ile kurganlar, Kazakistan’ın birçok bölgesindee bulunmaktadır. Üstürt'deki Baskuduk (Baş Kuyu) 1. mezarlığındaki Oğuz - Kıpçak dönemlerine ait olduğu öne sürülen Orta Asırlık Türk soyuna ait mezarlıktan savaşçı naaşıyla birlikte gömülen aşık kemiklerinin bulunması, Saka devrinde öbür dünya hayatına olan inanç kültünün olduğunu ispatlar (Resim $5 \mathrm{a})$.

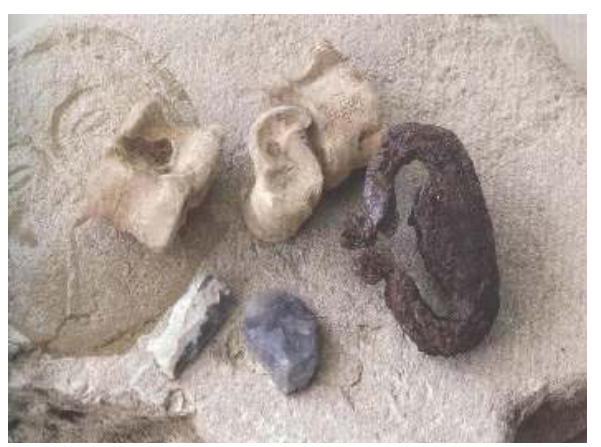

a

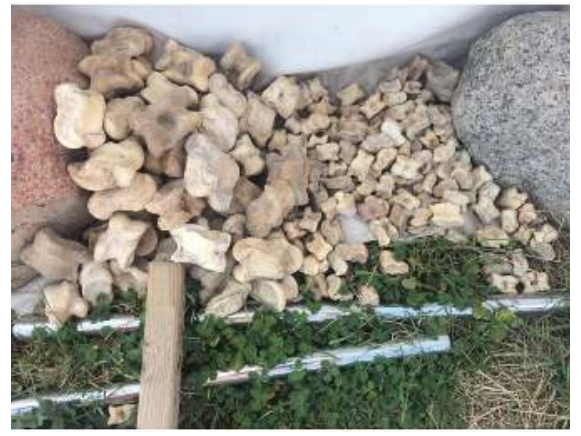

b

Resim 5: Gömülmüş aşık kemikleri: a. Üstürt. Baskuduk 1. mezarlı̆̆g ${ }^{8}$; b. Erken Türk şehri Kastek.Arkeolog Arnabay Nurcanov'un kazılarından. ${ }^{9}$

Altay'daki Pazırık kurganlarından omurga, sağrı kemikleriyle birlikte kuyruk yağı, koyun eti parçaları bulunmuştur. İnsan vücuduyla birlikte gömülmüş omurga ile sağrı kemikleri Volga nehri boyundaki ve Dağıstan’daki Türk soyluların kurganlarından da bulunmuştur. ${ }^{10}$ Tarih bize günümüzdeki Rusya'nın Altay bölgesinin Eski Türklerin mekânı olduğunu açık bir şekilde göstermektedir. Altay’ın Biysk

7 Olga Vişnevskaya, Kul'tura sakskih plemen nizov'ev Syrdar'i v VII-V vv. do n. e. po materialam Uigaraka, Nauka, Moskva 1973, s. 17, 31, 35, 45.

8 Resim 5 a - Samaşev vd, age., s. 273.

9 Resim 5b - Yazarlara ait fotoğraftır.

10 Mihail Griaznov, Pervyi Pazyrykskii kurgan, Moskva. Ripol Klassik. 2013, s. 52-53; Lef Gumilev, Sosedi hazar, Litres, Moskva 2004, s. 6; Arheologicheskaya otkrytiya 2007 goda, Litres, Moskva 2014, s. 538. 
şehri civarındaki ve Kemerev bölgesinde M.Ö. 9-11. asırlara ait olduğu bilinen Klasik Türklük döneminin kurganları korunmustur. Buradaki kurganlardan da insan naaşıyla birlikte gömülmüş koyunun sağrı kemikleri bulunmuştur. ${ }^{11}$

Esik kurganından bulunmuş Saka prensi olan (sivri başlıklı Sakalar - Saka tigrahauda) Altın Adam'ın sivri başlı̆̆ının üzerine kanatlı ve boynuzlu mitolojik at, pars, geyik, en uç kısmına ise koçun altın heykeli yerleştirilmiştir. Batı Kazakistan'dan bulunan "Altın Adam'ın" saukele (koni biçiminde, yukarıya doğru uzanan başlık) tipindeki başlı̆̆ının en uç kısmına da koçun altın heykelinin yerleştirilmesi, zoomorfik figürlerin dini idelojik anlamı, Güneş Tanrısı ile kabilelik totem arasındaki ilişkiyi gösterir. Kurganın büyüklüğü ve altınla kaplanmış giysilerle gömülmüş olması, sosyal statüsünün yüksek olduğunu bildirir. ${ }^{12}$

Sır Derya'nın aşağı akışı boyundaki Uyğarak mezarlığındaki 66. Kurgandan bulunan Saka kemerlerindeki koyun, koç alaşımlar, Saka'ların uygulamalı süsleme sanatındaki koyun ile koç figürleri, hayvan stilinin ana niteliklerinden biri olduğunu ispatlamaktadır. ${ }^{13}$

M.Ö. 4. asra ait olduğu sanılan 11. Berel kurganında erkek ve kadının kabrine 13 at koşumlarıyla birlikte gömülmüştür. At koşumlarındaki ağaçtan oyularak yapılan zoomorfik süs eşyaların yanında boyanmış koç başı da bulunmaktadır. Ağaç süs eşyaları öncelikle kırmızıya, onun üzerinden beyaza boyanmış ve daha sonra altınla kaplanmıştır. Bu renk uyumunun da kültler ve sihirler açısından anlamı büyüktür. Altın boya Güneş Tanrı'sının totemlikteki anlamıla ilgilidir (Resim 6). ${ }^{14}$ Sakaların "hayvan stilleri" M.Ö. 7-5. asırlarda Avrasya (Altay, Sibirya, Tuva, Karadeniz kıyları, Tuna, Orta Asya) topraklarında oldukça yaygin olmuştur (Resim 7). ${ }^{15}$ İan, Ön Asya'dan bulunan arkeolojik miraslar bu bölgede hayvan stillerinin 3-4. yüzyll öncelerinde yerleştiğini gösterir. Antik sanat eserlerindeki bu stil, Avrasya kabileleri arasında yeni bir anlam kazanarak, Avrasya İskit-Sibirya hayvan stilinin vatanı haline gelir.

11 Marya Zavituhina, Kurgannyi mogil'nik Srostki 2 na Altae. Soobshhenie Gosudarstvennogo Jermitazha, Vyp 27. Sankt-Peterburg 1963, s. 51-53; Kratkoe soobşeniya o dokladah i polevyh issledovaniyah Instituta istorii material'noj kul'tury, 5 vyp., Izdatel'stvo Akademi Nauk SSSR, Moskva 2007, s. 353.

12 Arheologiya Kazahstana, Oner, Almaty 2006, s.116; Kemal Akişev - Alişer Akişev, Proishozhdenie i semantika Issykskogo golovnogo ubora. V knige: Arheologicheskie issledovanija drevnego $i$ srednevekovogo Kazahstana. Almaty: Gylym 1980, s. 23-29.

13 Vişnevskaya, Uigaraka, s. 106; Sergei Tolstov, Po drevnim del'tam Oksa ifaksarta, Izdatel'stvo Vostoçnoi literatury, Moskva 1962, s. 185.

14 Arheologiya Kazahstana, s. 134.

15 Nataliya Polos'mak, Vsadniki Ukoka, Infolio-press, Novosibirsk 2001, s. 44-55. 

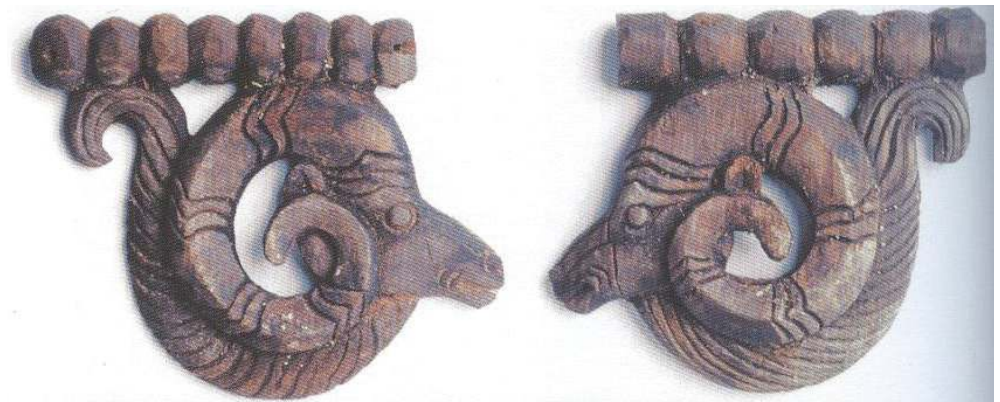

Resim 6: Koç başı. Ağaçtan yapılıp, altınla kaplanmıştır. Berel Mezarlı̆̆g $1^{16}$

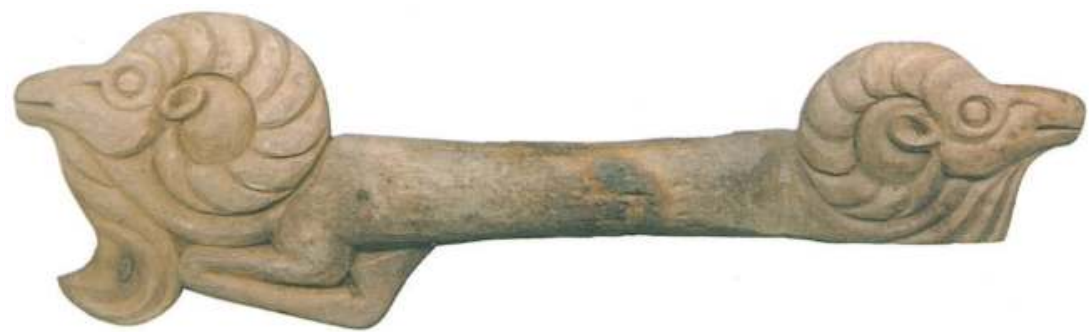

a

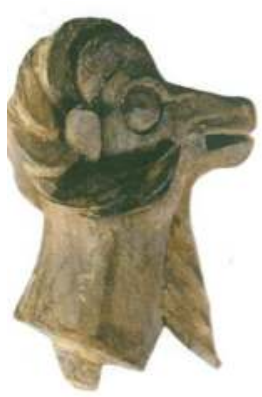

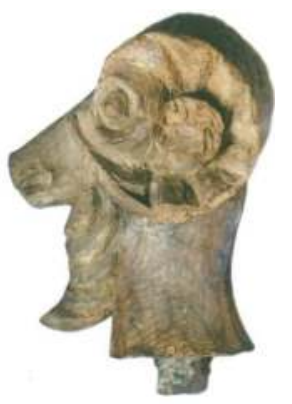

b

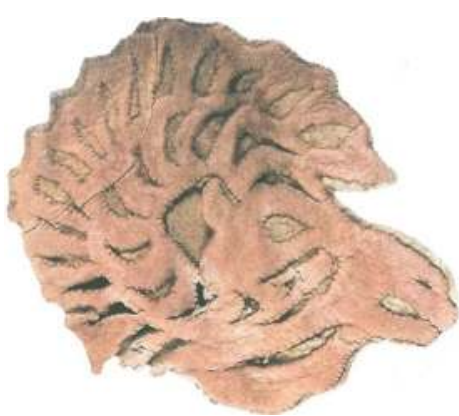

c

Resim 7: Koç başı. Dağ Altay. Ukok a. Ağaç. Ak-Alah Mezarlığı; b. Ağaç. Kuturgantas Mezarlı̆̆ı; c. Keçe. Ak-Alah Mezarlı̆g $1^{17}$

Sır Derya nehrinin orta ve aşağı akışı boyunan bulunan koç figürü resmedilen ve koç boynuzu işlenmiş seramik koleksiyonlar, Kazak topraklarında koç kültünün ev yaşa-

16 Arheologiya Kazahstana, s.134.

17 Polos'mak, Ukoka, s. 65, 103, 217. 
mında önemli bir yere sahip olduğunu gösterir. Tanınmış arkeolog Karl Baypakov, koç figürlü arkeolojik seramik eşyalar kronolojisini aşağıdaki gibi dört döneme bölerek incelemiştir: M.S. 1. asırdan 8. asra kadarki koçun tam olarak şekli; 8-12. asırlar aral1ğindaki koçun stilleşmiş figürü ve koç figürünün tutacak şeklindeki görüntüsü; 1314. asırlar aralığındaki koç protomunun tam bir şekli; 15-18. asırlar aralığındaki koç boynuzu figürü (Resim 8 -10). ${ }^{18}$

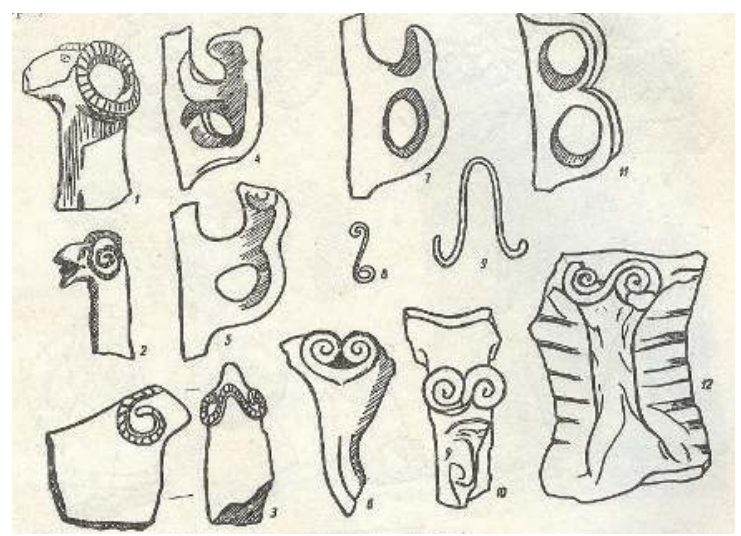

Resim 8: Koç. Seramik figürler ve mutfak aletleri kolları. 1-7 yüzyıl.

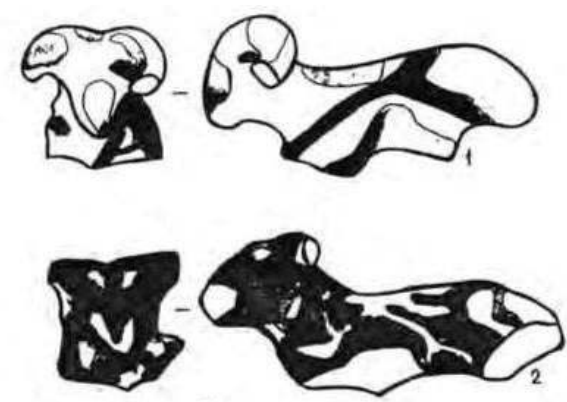

Resim 9: Koç. Seramik figürler. 8-12 yüzyıl. 


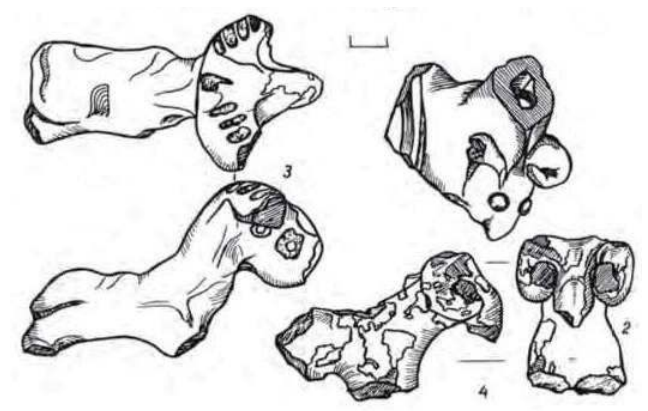

Resim 10: Koç. Seramik figürler. 13-14 yüzyıl.

Tutacak kısmına koç şekli tasvir edilmiş çömlekler ile kaplar, "zoomorflu tutacaklı seramikler" diye adlandırılır. Koç şekilli seramiklerin asıl koleksiyonunu Otırar ve Sır Derya vahalarının seramikleri oluşturmaktadır. ${ }^{19}$

Sır Derya'nın aşağı akışı boyuna yerleşmiş olan Kanlı kabilesinin Tompak Asar kentinin M.Ö. 1. yüzyıla ait olduğu düşünülen kültür katmanından koçun tam bir şekli resmedilmiş seramik eserler bulunmuştur. Arıs nehrinin yukarı akışı boyundan bulunmuş kazan kapağının tutacağı olarak boyun kısmı uzun olarak yapılmış koç başı şekli kullanılmıştır (Resim 11 a,b). Arkeolojik seramik kaplarda koç başı şeklinin çok sık meydana çıkması, eski kabilelerin dünya görüşleri ile inanç sistemlerinde koçun iyilik ve refah sembolü olduğunu göstermektedir. ${ }^{20}$ Kapların tutacak kısımlarındaki koç, koyun figürleri, eski kabilelerdeki bolluğun da sembolüdür.

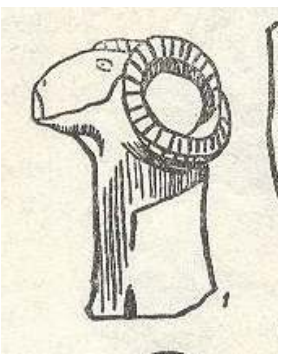

a

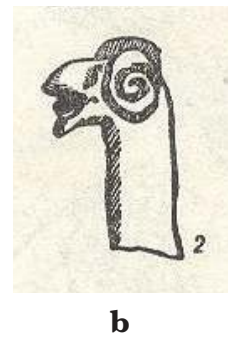

b

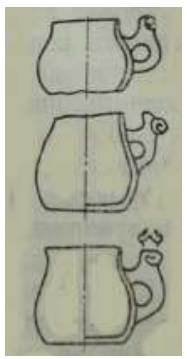

C

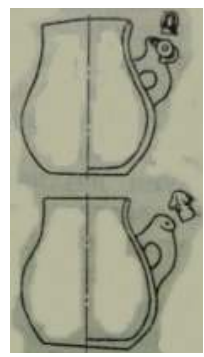

d

Resim 11: a-b. Kazan tutacakları; c-d. seramik kaplarda koç başı ${ }^{21}$

19 Kemal Akişev - Karl Baypakov - Lev Erzakovich, Drevnii Otrar, Gylym, Almaty 1972, s. 32-38; Serjan Ahinzhanov, K voprosu o znakah na keramike pozdnesrednevekovogo Otrara, V knige: Drevnosti Kazahstana, Almaty 1975, s. 52-57; Ludmila Levina, Keramika nizhnei i srednei Syrdar'i I I tysiyacheletii n.e., Nauka, Moskva 1971, s. 76-89, 178-188.

20 Baypakov, "Kul't barana...", s. 33.

21 Baypakov, age., s. 33; Levina, tysiyacheletii n.e., s. 232. 
Koç şeklinde tutacağı olan seramik kapların yaygın olduğu yer, Sır Derya'nın orta ve aşağı akış boylarıdır. Sır Derya vadisine ait olduğu bilinen koç figürlü seramik eşyalar, bu bölgedeki Jetiasar, Kauınşı, Otırar, Karatau medeniyetleriyle çok sıkı ilişkilidir. Bu medeniyetler ilk olarak S.P. Tolstov'un yönettiği Harezm araştırmaları sırasındaL. Levina'nın çok dikkatini çekmiştir. L. Levina seramik eşyalar üzerinde yapılan incelemelere dayanarak bu bölgedeki medeniyetlerin oluşma sürecini üç döneme ayırarak inceler: ilk dönem bütün medeniyetler için: M.S. I. asırdan M.S. 3-4 asırlara kadar; ikinci dönemde Kauısş1, Otırar ve Karatau medeniyetleri III. asrın sonu ile 4. asrın başından 5. asra kadar ve Jetiasar medeniyeti 4-7 asırlar aralığında; üçüncü dönemde Otırar, Karatau medeniyeti 6-8 asırlar, Kauınşı medeniyeti 6-8 asırlar, Jetiasar medeniyeti 7-9 asırlar olmak üzere. Bu arkeolojik medeniyetler, Sır Derya'nın orta ve aşă̆ı akışı etrafını mekân eden Erken önem Türk kabilelerinin eski medeniyetlerine aittir. Onlardan biri, Toharlar medeniyeti. ${ }^{22}$

Çağımızın başlarında koç figürünü resmetme sanatı Orta Asya'nın doğu, güney ve güney batı bölgelerinde, İdil boyunda, Kafkasya bölgesi'nde, Don nehri etrafinda, Kuban bölgesinde yaygınlaşmıştır. Bu bölgelere zoomorfik seramiğin yaygınlaşması Erken dönem göçebelerin hareketleriyle alakalıdır. ${ }^{23}$

Otırar seramiklerindeki kapların tutacak kısımlarındaki koç figüründen başka stilleştirilmiş ya da tam olarak geyik, tilki şekilli görüntüler de vardır. ${ }^{24}$

Rus bilim adamı Bella Vaynberg, Harezm sikkelerinde sık sık karşılaşılan “ $\backsim$ ” işaretini Kauınşı medeniyetinin olarak bilinen Sır Derya'nın orta akışı boyunda yapılmış olan seramik eşyalardaki koç figürüyle ilişkilendirir. " @ işareti konulmuş sikkeler Harezm araştırmaları sırasında da bolca ortaya çıkmıştır ve hem de bu işaret Doğu Avrupa'da da mevcuttur. ${ }^{25}$ Çünkü, bu işaret Eski dönemlerde koç boynuzu yerine geçmiştir (Resim 12). M.S. 3-4. asırlarda Eski Turan Sır bölgesindeki kabilelerin bir kısmı Harezm’e yerleşmiştir. Harezm incelemeleri sırasında Janbas şehrinden koyunun metal ve seramik alaşımları, Tesik şehrinden seramik koç figürü, Kanat şehri seramiklerindeki koç boynuzu şeklindeki süslemeler, Erken dönem kabilelerinin etnik ve kültürel bağları neticesinde meydana gelmiştir. ${ }^{26}$

Harezm bölgesinin Kerderi seramik çanak-çömlekleri ile Otırar vahası ile Sır

22 Levina, age., s. 76-89; Tolstov Sergei, Po drevnim del'tam Oksa i Jaksarta, 1962, s. 186.

23 Levina, age., s. 230-240.

24 Arheologiya Kazahstana, s. 218.

25 Bella Vaynberg, Monety drevnego Horezma, Nauka, Moskva 1977, s. 39; Sergei Tolstov, Drevnii Horezm, Opyt istoriko-arkeologiçeskogo issledovanïa, Izdanie MGU., Moskva 1948a, s. 176-182.

26 Sergei Tolstov. Drevnii Horezm, age., s. 89, tablo; Sergei Tolstov. Po sledam drevnehorezomskoi civilizacii, Izdatelstvo Akademii Nauk SSSR., Moskva 1948, s.278-279. 
Derya'nın aşağı akışı boyundaki seramik kapların birçok ortak özellikleri vardır. Çağımızın başlarına ait olduğu sanılan Arıs zoomorfik figürleri, daha sonraki 7-9. asırlarda Kuzey Kafkaslar'da da meydana çıkmışır. Bilim adamları bu kültürel mirası, Alan kabilesi'nin Sır Derya'nın orta akışı boylarından Kafkas'lara taşınmasıyla ilişkilendirmektedir. ${ }^{27}$ Anadolu halk kültüründeki zoomorfik kültüler, Türklerin Orta Asya'dan Anadolu'ya getirdikleri önemli değerlerden biridir. ${ }^{28}$

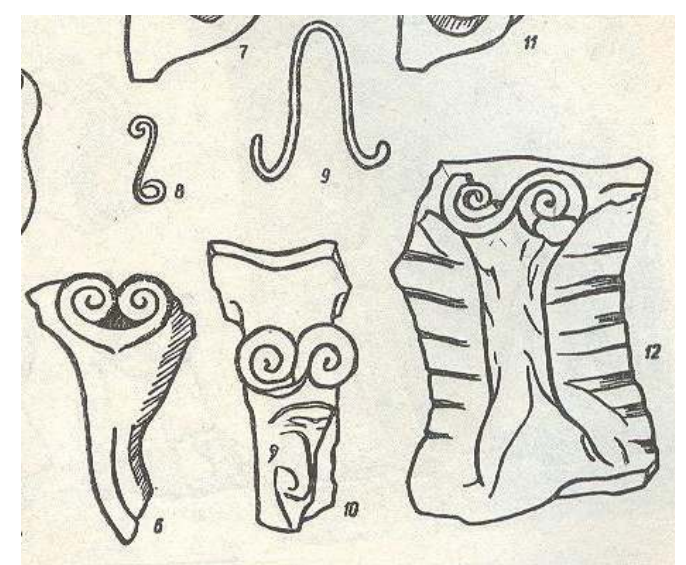

Resim 12: Koç başı olarak resmedilmiş damgalar ile figürler. ${ }^{29}$

Zoomorfik şekilleri günlük yaşamda kullanma medeniyetini Kanlı'lardan Kengeres’ler (Peçenekler), onlardan da Oğuzlar miras edinip yaşatmıştır. Oğuzlar, Sır Derya ve Karatau Vadisi'ni mekan edip, Jankent, Jent, Barşınkent, Sauran, Sütkent, Sığanak, Karnak, Karaçuk, İshidjap şehirlerini geliştirmiştir. Oğuz kabilesinin eski mirası koç başlı seramik firının ağzı, günümüze kadar korunmuş olan eşsiz anıtlardan biridir. Çift koçun gövde kısmına kanatlı koç boynuzu figürü resmedilmiştir (Resim 13). ${ }^{30}$

Ekmek pişirilen firının ağzına koç figürünün resmedilmesi olayı, Özbek, Karakalpak halklarının eski kültürel anıtlarında karşımıza çıkar. ${ }^{31}$

27 Vaynberg, Horezma, s. 39-40.

28 Nilgün Dalkesen, “Orta Asya'dan Anadolu'ya Türk Kültüründe Geyik Kültü”, Milli Folklor, 106 (2015), s. 58-69.

29 Resim 8-12 - Baypakov, "Kul't barana...", s. 32-35.

30 Sergei Agadjanov, Oçerki istorï oguzov i turkmen Srednei Azii IX-XIII vv., Ylym, Aşhabad 1969, s. 129132.

31 Gleb Snesarev, Relikty domusul'manskih verovanij i obrjadov u uzbekov Horezma, Moskva 1969, s. 115- 


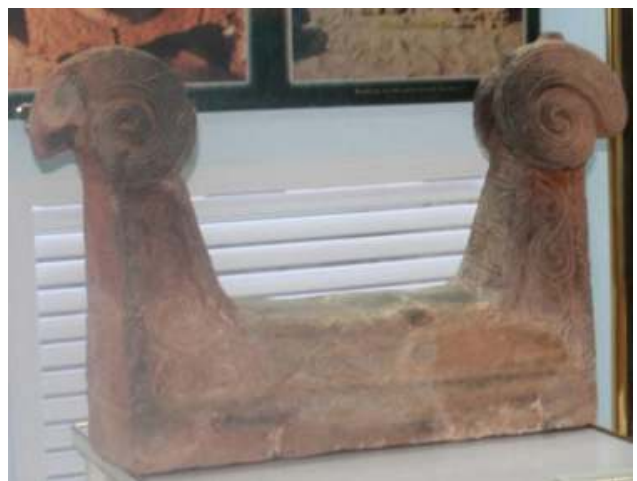

Resim 13: Koç başlı firın ağzı. Jankent şehrinden bulunmuştur. Korkıt Ata adındaki Kızıl Orda Devlet Üniversitesi müzesi. ${ }^{32}$

Koç figürlü seramik eşyalar, Karluklar döneminde Yedi Su bölgesinde yaygınlaşmıştır. Yedi Su bölgesindeki Talhir adlı Orta Asırdan kalma şehirden bulunan pişmiş topraktan yapılmış koç başı, çok dikkat çeken eserlerden biridir. Araştırmacı bilim adamları, Karluk kabilesi'nin şehirleri ile yaşadıkları mekanlardan bulunan zoomorfik görüntüleri Kanlı medeniyetinin bir devamı olarak kabul etmektedir (Resim 14). ${ }^{33}$

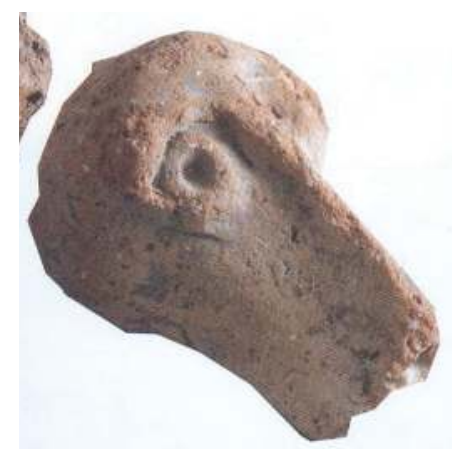

Resim 14: Koçbaşlı. Seramik bir eser. Talhir şehri. 11-12. yüzyll $1^{34}$

116.

32 Resim 13 - Yazarlara ait fotoğraftur.

33 Alexandr Bernştam, Istoriko-arheologicheskie ocherki Central'nogo Tiyan'-Shaniya i Pamiro-Alaya, Materialy i issledovaniya po arheologii SSSR. Vyp 26.1952, s. 153-154; Arheologiya Kazahstana, s. 199.

34 Arheologiya Kazahstana, s. 199.

Belleten, Aralık 2020, Cilt: 84/Sayı: 301; 907-958 
Oğuz Devleti Kıpçaklar’ın baskısıyla 11.yüzyılda dağılmış olmasına rağmen, 1314 yüzyıllarda Otırar, Sığanak, Sauran, Jent, Yesi şehirleri tekrar canlanıp gelişerek, Sır Derya Vadisi'nde önemli bir ticaret ve kültür merkezi haline geldi. Bu sebeple, çömlekçilik (çanak çömlek) sanatında koyun, koç şekillerini resmetme geleneğinde daha fazla gelişmeler oldu.

Hayvanlarla, ev hayvanlarıyla alakalı arkaik dinlerin birçok elemanları, Zerdüştlük, Şamanizm, Totemizm ile kutsallaşarak, daha sonraİslam dininin içine de karışarak, nesilden nesile süregelmiştir. Sır Derya Vadisi’ndeki Saka'ların eşyalarındaki, Erken Dönem Kanlı'ların seramik eşyalarındaki, sikkelerindeki hayvanlar, özellikle de koç şekli, onlarn dünya görüşünde «tuman(talisman, muska) görevini görmüştür. Oğuz’lar arasında «koç kültü» kabilenin koruyucusu olarak bilinmiştir. Erken Dönem Kanlı'lardan başlayarak, Orta Asırlık Közeşiler dahi totem olan «koç» figürünü oluşturma işlemini Kazak ve başka da Türk soylu halklara miras bırakmıştır. ${ }^{35}$

\section{Koyun Taşlar ile Koç Taşlar}

Kazak topraklarında kabir başına konulan koyun heykelli mezar taşlarıyla koç taşlarının etimolojisi, koyun, koçun taştan yapılmış heykellere benzemesiyle alakalıdır. Koyun taş, koç taşların farklı örnekleri Aral ve Hazar aralığında çok kullanılmıştır. Anıt uzmanlarının belirlediklerine göre bu heykellerin özellikle çok yaygın oldukları dönemler 13-14. yüzyllardaki Bozaşşı'daki 'Salor Dönemi'dir”. Salor dönemi, 13-14 yüzyllardaki Oğuz-Türkmen kavimlerinin önemli göçlerine verilen isimdir ve "Salor Joskını" (Salor Felaketi) de denmektedir. ${ }^{36}$

Bir mezar taşı olarak inşa edilen koyun taşlar ile koç taşlar, Kazak halkının süsleme ve uygulamalı sanatındaki taş keski sanatının seçkin örneklerinden biridir. Mangıstau koçtaşları yerel kuyruklu koyunların taşa oyulmuş figürleridir. Temeline kökörüs (yeşillik otlak alan), geometrik şekillerle birlikte silah, yılkı, damgaların kabartma şekilleri resmedilmiştir (Resim 15-16).

35 Agadjanov, IX-XIII vv, s. 137-138; Baypakov, "Kul't barana...”, s. 44-45; Çokan Valihanov, Sobraniye sochineniyi v pyati tomah, Vol. 4, Glavnaya redaksiya Kazahskoy sovetskoy ensiklopediyi, Almaty 1985, s. 106.

36 Sergei Tolstov, Goroda guzov, Sovetskaya etnografiya 3 (1947), s. 101; Ajiğali, age., s. 7. 


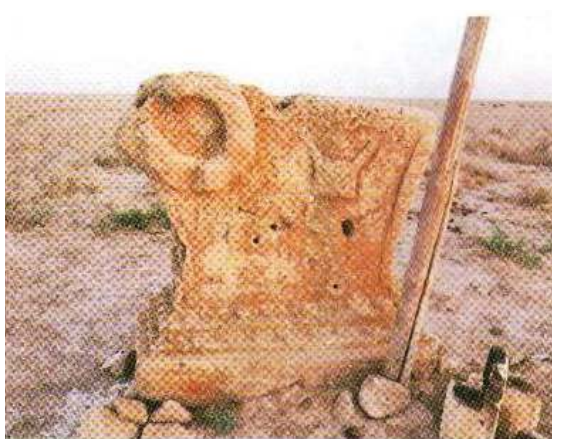

a

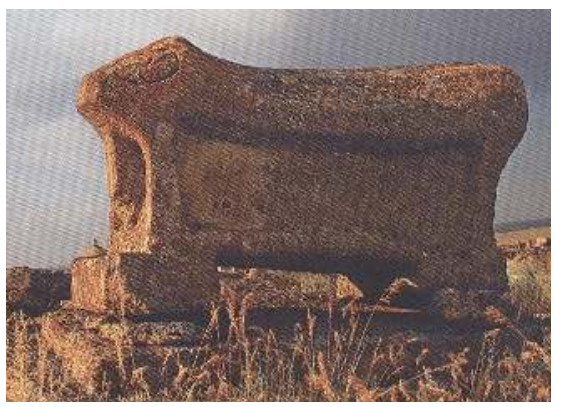

c

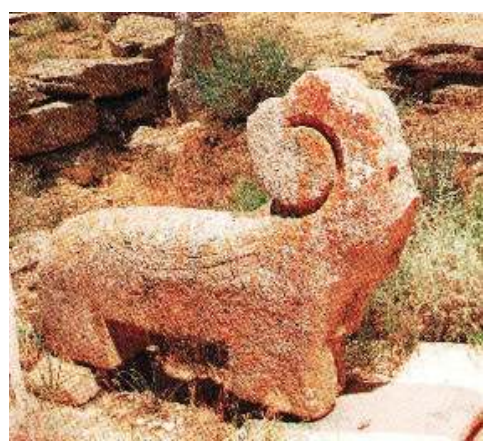

b

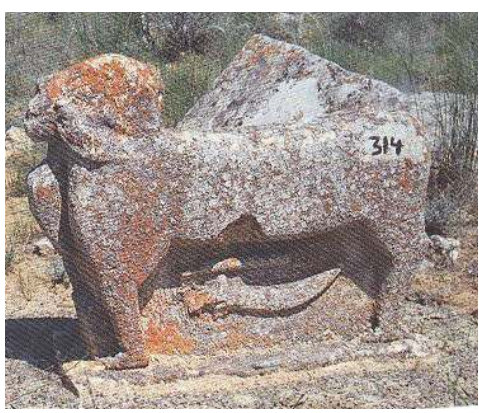

d

Resim 15: Mangıstau koçtaşları: a. Bozaşşı, Akşınırau yerleşim bölgesi. 13-14 yüzyıllar; b. Kuruk Mezarlıği; c. Beyneu Mezarlığ1; d. Masat Ata mezarlığ ${ }^{37}$

Kazak topraklarında koyun heykelli mezar taşlarının bulunduğu veen yaygın olduğucoğrafi bölgelerin Batı bölgesindeki Mangıstau, Donıztau, Üstürt mezarlıkları olduğu bilinmektedir.19. yüzyılda Kazak topraklarının batı kesiminde İslamhızla gelişir. Kazan, Ufa, Orenburg dini okullarının Kazak topraklarının batı kısmına sınır yakınlığı, Hive'yle aradaki iletişim yollarının Kazak topraklarının batı tarafindan geçmesi, dini merkezlerle ilişkilerin hızla gelişmesine yol açmıştır.19. yüzyılda, Kazak topraklarının batısında İslam okullarının daha fazla olması nedeniyle, hayvanların gerçek görüntülerinin İslam dininin ilkeleriyle çelişiyor şeklindeki görüşlerden dolayı, koyun ve koçların gerçek görüntülerini oyma tarzı, şematik stil şeklindeki oymaya geçmeye başlamıştır. 19. ve 20. yüzylların başlarına ait olduğu tahmin edilen mezarlardaki koyun heykellimezar taşları, taş oymacılı̆̆ı 
sanatındaki üslup geçişini, "modern koyun heykelli mezar taş" modelini ortaya koyar. Yazarın Kazak topraklarının batı kesimine yaptığı etno-arkeolojik araştırmalar sırasında, daha önce kaydedilmemiş ve keşfedilmemiş koyun heykelli mezar taşları bulunup fotoğraflanmış ve kaydedilmiş̧ir. Bunlar arasında Donıztau, İzenagaş, Ayrıktı koyun heykelli mezar taşları vardır (Resim - 16).

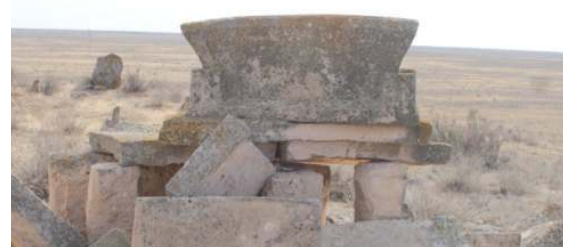

a

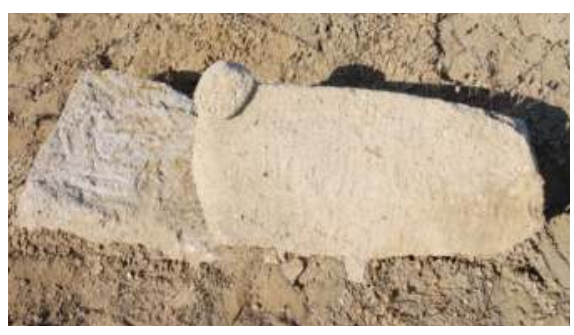

c

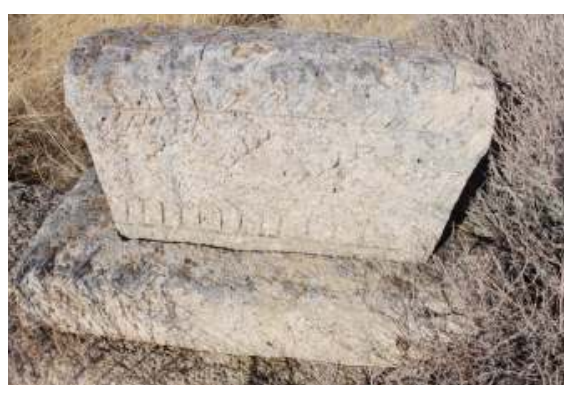

e

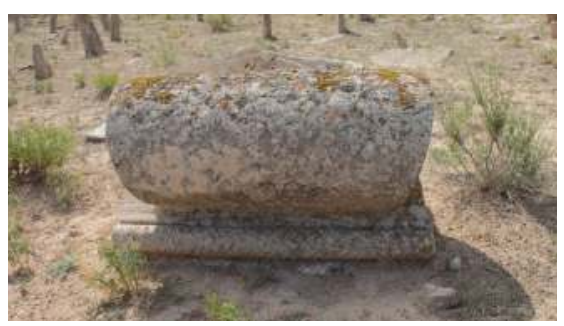

b

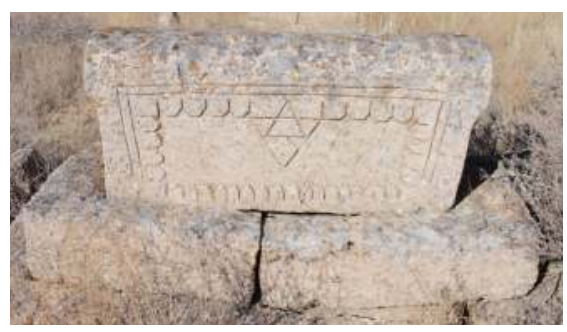

d

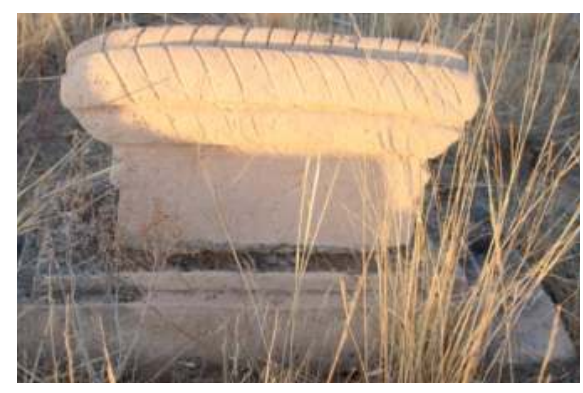

f

Resim 16: Modern koyun heykelli mezar taş - Koçtaşlar, 19. ve 20. yüzyılların başları: a. Jolaskan mezartaşı, Mangistau; b. Seisem Ata mezartaşı, Mangistau; c. Taskabak mezartaşı, Doniztau; d-e. Izenagaş mezartaşı, Usturt; f. Kursai mezartaşı, Üstürt. ${ }^{38}$

38 Resim 16 - Yazarlara ait fotoğraftır. 
Koçtaşların anlambilimsel geçmişi, Erken Dönemlerdeki Saka, Kanlı, Sarmat kavimlerinin sembolleriyle, ataların kültüyle, tabiata sı̆̆ınmayla, çoğalıp gelişme düşüncesiyle, mitolojik dünya görüşüyle yakından alakalıdır. Kahramanın, savaşçının, aşiret sahibinin, aile reisinin bu dünyada yaptı̆̆ı hizmetlerine duydukları ebedi saygının ifadesi olarak kabirlerinin üzerine koçtaşlar yerleştirmişlerdir. Koçtaş, erkeğin sosyal statüsünün yüksek olduğunu, onun çok güçlü olduğunu hep hatırlatan sadece bir anıt olarak değil, rahmetlinin oteki dünyadaki koruyucusu ve talismanı da olmuştur. ${ }^{39}$ Oğuzlar'ın kültürüne has mezar taşı görevini gören koçtaş, Orta ve Orta asır sonlarındaki koçtaşların prototipidir denebilir (Resim 17).

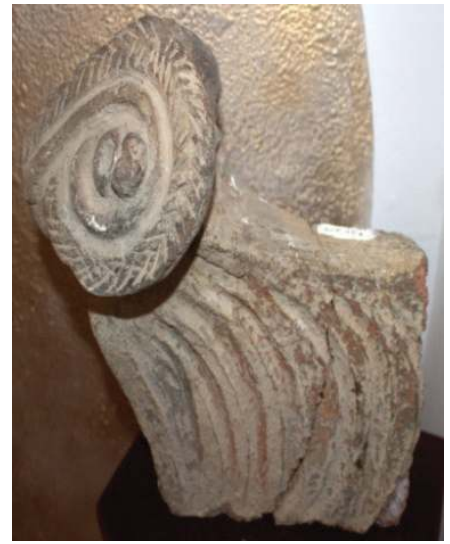

a

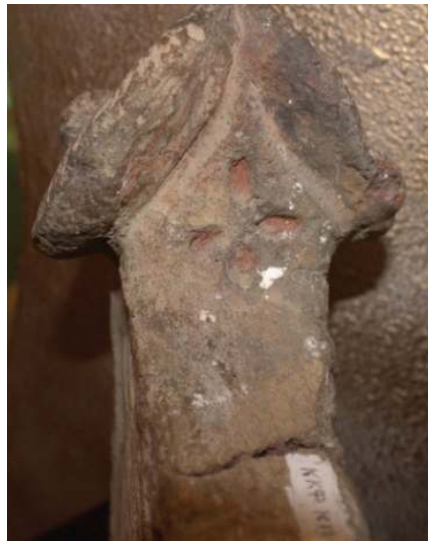

b

Resim 17: Jankent'ten bulunan koçtaş: a. yan açıdan bakıldığında b. boyun kısmından bakıldığında. Dede Korkut kaynakları müzesi kolleksiyonundan (Kızılorda, Karmakşı) ${ }^{40}$

Koyun taşlarını miras olarak yaşatan başka da soylar vardır. Kazak topraklarında mevcut olan koyun taşları ile Sibirya'daki Altay bölgesi, Moğolistan, Çin, Kırgızistan, Azerbaycan memleketlerindeki koyun taşlarını birbirlerinden ayıran özellikler, onların bezenme şekilleri ile stillerindedir. Mesela, Tunceli koç taşlarına genellikle kozmogonik süslerle kuşların şekilleri oyulmuştur. Bu özellik Türklerin geleneksel dünya görüşü ve inanç sistemiyle yakından ilgili (Resim 18 ${ }^{41}$, Kazak topraklarında 
bulunan koyun taşlarındaki silah görüntüleri, erkeğin bir orduya dâhil olmasıla, göçebelerin askeri sanatıyla, silahla ilgili inanç sistemiyle alakalıdır.

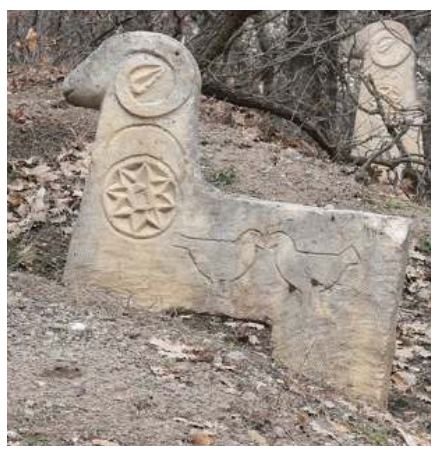

$\mathbf{a}$

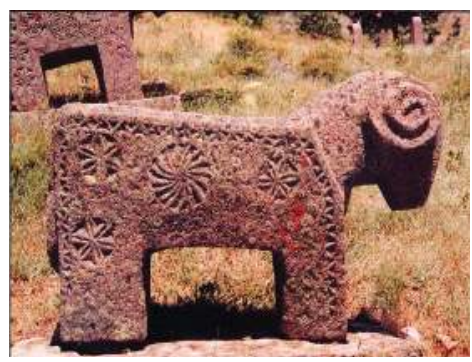

c

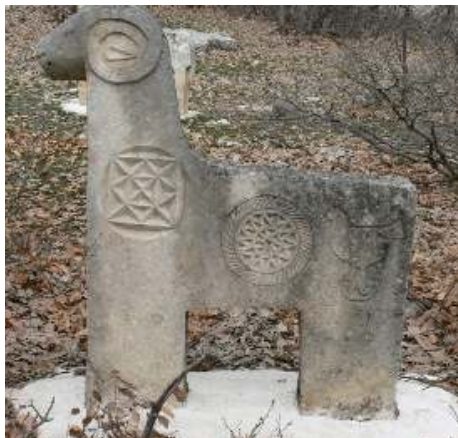

b

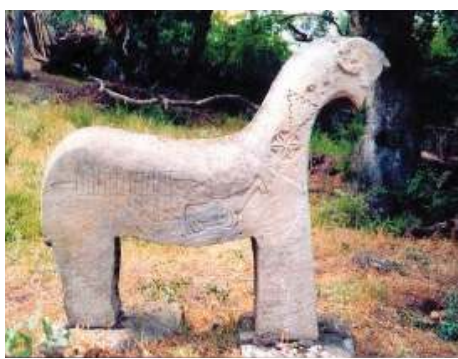

d

Resim 18: a, b, c, d - Tunceli koçtaşlari ${ }^{42}$

Anadolu Türklerine ait koyun heykelli mezar taşlarının bir başka özelliği de Anadolu topraklarında koyunların dört ayak üzerinde durduğu görüntülerinin daha fazla olmasıdır. Oysa Kazak topraklarındaki koyun heykelli mezar taşlarında genellikle dört ayak üzerinde bükülmüş olan koyun şekillerininin oymalarına daha çok rastlanmaktadır. Etno-arkeolojik araştırmalara göre, bu ritüel "kurban" kavramı ile ilişkilidir (Resim 15b; 16).

Koyun taşlar ile koç taşların stilize edilmiş, heykelleştirilerek stilize edilmiş iki çeşidi aslında Sağız nehrinin güney bölgelerinde mevcuttur. Bu bölgede koçtaşlara göre koyun taşların figürleri daha fazladır. Oralarda koç taşlara arkar taş (dağ koyunu) da derler. Bu

Sessiz Dili Damgalar, s. 354-373; Tuncer Gülensoy, Damgalari, s. 26-32.

42 Ertuğrul Danık, "Koç ve At şeklindeki Anadolu...", s. 20-21. 
da elbette bazı koç boynuzlarının kıvrılarak, dağ koyunlarının boynuzlarına benzemesiyle ve boynuzlu hayvanlar arasında dağ koyunu, dağ keçisi kültlerinin eskiden çok yaygın olmasıyla ilgilidir. ${ }^{43}$ Mezar başına koyun taş, koç taş yerleştirmek Aral, Hazar civarını mekân eden Türk soylu halkların, yani Türkmen, Azerbaycan, Kürt, Dağıstan'lı v.b. da halklarda görülür (Resim 19). ${ }^{44}$ Azerbaycan ve diğer dağlık bölgede yaşayan halkların arasında koyun taşların çok yaygın olması, onların etnik kökenlerinde Oğuz boyu özelliklerinin olmasılla bağlantılıdır ve Azerbaycanlılar koyun taşlarını "Daş qoç" diye adlandırırlar.

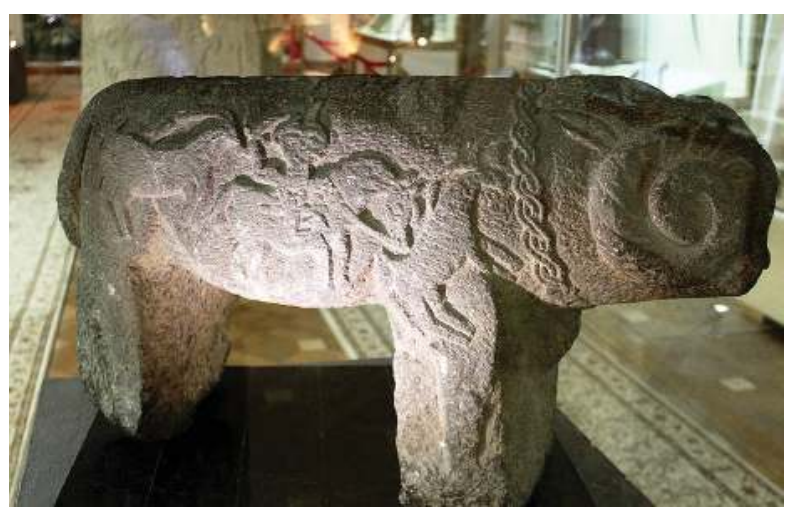

Resim 19: Nahçıvan koyun heykeli. 16. yüzyıl. Azerbaycan Tarihi Müzesi.

Koyun, koç şekillerinin Oğuz kabilesinin totemlerinden biri olması, Erken Türk boyları arasında koyun, koç kültünün çok erken dönemlerde yaşatılmaya başlandığına işaret etmektedir. Koyun, koç şekilleri sadece totemizm kalıntılarıyla değil, Zerdüştlük unsurları ve erken dönem kabilelerinin hayvanları kutsamalarıyla ilgili karmaşı dünya görüşüyle de alakalıdır.

Azerbaycan'da koyun heykelli mezar taşlarının yaygın oluşu, ilk olarak Selçuklular ve ardından Karakoyunlu ve Akkoyunlu kabileler birliğinden oluşan Oğuz Türklerinin faaliyetleri ile bağlantılıdır. Kabile ittifaklarının bayraklarında da siyah ve beyaz koyunlar tasvir edilmiştir. Azerbaycan topraklarında Karakoyunlu ve Akkoyunlu gibi güçlü Türk devletlerinin ortaya çıkmasıyla birlikte koç heykelleri biçimindeki mezar taşları da büyük oranda artmıştır. Bugün de Azerbaycan'da "Akkoyunlu” ve "Karakoyunlu" adlı yerleşim birimleri bulunmaktadır. Bu durum, adı geçen kabile birliklerinin

\footnotetext{
43 Ajiğali i, age., s. 13.

44 Ajiğali, age., s. 13-14.
} 
Azerbaycan topraklarında oldukça geniş bir alana yerleşmiş olduklarını ve Azerbaycan halkının etnogenezinde önemli bir payı olduğunu göstermektedir. ${ }^{45}$

Taş heykeller yapmayı meslek haline getiren ustalar, eski dönemlerde taş heykelci, daha sonraları taş̧̧ı olarak adlandırlıp, onlar kendi bildiklerini sonraki nesillere ve yardımcılarına öğretmişlerdir. ${ }^{46}$

Kazak topraklarındaki koyun taş, koç taşların tarihi, medeni ve manevi kaynak olması açısından eşsizulusal miras olduğunu söylemek mümkündür. Günümüzde onlar taş keski sanatının ve mimari anıtların eşsiz bir örneği olarak devlet korumasındadır. Koyun taş, koç taşların büyük bir bölümünün yer aldığı Kazak topraklarının Batı bölgesi, günümüzde petrol ve gazın yoğun olarak üretildiği ekonomik bir bölgedir. Bu durumdan tarihi anıtların zarar görmemesi için devlet gerekli tedbiri almaktadır. Bu bölgeleri mekan etmiş olan ve zamanında göçebe ve yarı göçebe şekilde hayvancılıkla uğraşan atalarımızın eşsiz mimarî mirası, sadece Kazak halkının değil, eski Turan topraklarını mekan eden halkların da paha biçilmez mirasıdır.

\section{Koyun ve Koç Taşlarla İlgili İnanç Sistemleri}

Kazak halkının dünya görüşünde dört tülük (deve, at, koyun, sığır gibi hayvanların genel adı) hayvanın koruyucu pirleri vardır. Yılkı piri - Kambar Ata ya da Yılkıcı Ata (At Sürüsü Sahibi), deve piri - Oysıl Kara, büyükbaş hayvan piri - Zengi Baba, koyun piri - Şopan Ata, keçi piri - Şekşek Ata'dır. Onlar sadece dört çeşit hayvanın pirleri değil, insanların da yoldaşı, yardımcısıdır. Semerkand yakınlarında Şopan Ata (Çoban Ata) türbesi mevcuttur. Mangıstau'da Şopan Ata yeraltı mescidi, Şopan Ata eski mezarı vardır.

Halk arasında yaygin olan bir efsaneye göre, Şopan Ata Hoca Ahmet Yesevi'nin talebesi olmuştur. Günlerden bir gün Ahmet Yesevi talebelerini denemek amacıyla keçe çadıra toplamış ve asasını çadırın kubbesinden dışarı firlatarak: «Asayı kim önce bulup getirirse sahibi de o olur» demiş. Şopan Ata lâkaplı talebesi de uzun bir süre aradıktan sonra asayı Mangıstau'da bulmuş. Daha sonraları oradaki mezar Şopan Ata olarak adlandırılmıştır.

Bir başka efsaneye göre, Musa adlı delikanlı kuyunun ağzındaki taş kapağı kaldıra-

45 Farid Alekperli, Zoomorfnye memorial'nye pamjatniki Azerbaidjana, Tezisy III Mezhdunarodnoi nauchnoi konferencii "Turkologicheskoe Iskusstvoznanie: Problemy i Perspektivy". Baku 2013. s. 33.

46 Ajiğali, age., s. 60. 
mayan iki kızla karşılaşmış. Musa, kızlara yardım edip, kuyudan su çekip, kızların koyunlarını sulamış. Kızlar Musa'yı evlerine davet edip, babalarıyla tanıştırmış. Babası da körmüş. O, Musa’yı çoban olarak evine kabul etmiş. 9 sene sonra Musa oralardan ayrılmak istemiş. Bunu duyan ihtiyar, 1 sene daha kalırsa gelecek sene doğacak olan kuzulardan ak olanlarının hepsini Musa’ya vereceğini söylemiş. Bir sonraki sene de doğan bütün kuzular ak olarak doğmuş. Böylece iki sene içinde doğan bütün hayvanlar Musa'nın olmuş. Sonrasında ihtiyar Musa'yı küçük kızıyla evlendirmiş ve koyun sürülerinin hepsini Musa'ya verip, onu Şopan Ata olarak adlandırmışmış (araştırmacıların gezi notlarından). Şopan Ata’yi Kirgiz halki da koyunlarin piri olarak kabul ederler. ${ }^{47}$

Kazak halkı dört tülükten "deve - zenginliği, yılkı - süsü, inek - akı (süt ürünlerini), keçi - kolaylığı, koyun - efendiliği” ifade eder diye açıklar. Kazak halkının kültür mirası içinde korunmuş olan koyun ile çobanın atışma şiiri, koyun kültünün tabiatla ilgili oluşunun bir başka delilidir. ${ }^{48}$

Kazakların koyun yetiştiricilikle ilgili yerine getirdikleri ritüel önlemlerin bazıları günümüze kadar neredeyse hiç değişmeden ulaşmışken, bazıları da günümüzde kullanılmamaktadır. Eskiden Kazaklar koyunların zamansız, yani kışın yavrulamalarını önlemek için koçun üreme organını keçe veya deri çantayla sarıp bağlamışlardır. Küyek adı verilen bu bağlama işlemini kadınlar yapmıştır. Sağım yapılan koyunların sonbahardaki çiftleşme zamanını ve koyunlar nevruzda (martta) yavrulasın diye hesap ederek, koçun üreme organından küyeğ $i$ (kapattıkları parçayı) ekim, kasım aylarında çıkartmışlardır. Küyeklerini çıkarttıklarında batıl inançlarına göreevin büyük hanımının ya da çok çocuklu bir kadının koçun başını tutmasını istemişlerdir. Koç başını tutan kadın donunu aşağı indirip, tekrar giymiştir. $\mathrm{Bu}$ batıl inanç, koyunlar hızlı bir şekilde üresin, yavrulasın ve dişi kuzuları çok olsun gibi bir niyetle yerine getirilmiştir. Koyun sürüsünün sahibi koçun ağzını açıp ağzına "kuzularn darn gibi çok olsun" niyetiyle bir avuç darı koymuştur, "sidiğin altın olsun, ürettiğin koyunlarn ölmeden çoğalsın" diye koç için dua etmiştir. Bu, üreme çok olsun, koyunların hepsi gebe olsun anlamını taşır. Daha sonra koçu sağım yapılan koyunlarının yanına koymuşlardır. Koyunların Nevruzda yavrulamalarına “töl tiüstü” (döl düsstü) derler. $^{49}$

47 Mayramgül Diykanbayeva, "Kirgizlarda “Tört Tülük” hayvanla ilgili inaniş ve Uygulamalar", Milli Folklor. 115 (2017), s. 140.

48 Abubakir Divayev, "Pastuhi". Turkestanskiye vedomosti. 4 (1905), s. 14.

49 Abubakir Divayev, Tartu, Ana tili, Almaty 1992, s. 171. 
Koçu koyunların yanına koyduktan sonra sürü sahibinin eşi köy kadınlarına tatlılarla çay ritüeli yapmıştır. Bu gelenek şaşıratkı (saçılmak) diye adlandırılıp, o da koyunlarımız ikiz ikizden yavrulasın, döl çok olsun niyetiyle yapılmıştır. Günümüzde "şaşıratkı" yapma geleneği yerine getirilmemektedir. Kazak topraklarının Sır Derya bölgesinde koçun üreme organını keçe veya deri çantayla sarıp bağlama geleneği 1980’li yıllara kadar sürdürülmüştür. Günümüzde ise bu gelenek yaşatılmadığı için koyunlar kışın da yavrular olmuştur. Kışın doğan kuzular çalışma evine getirilip bakılır veya özel olarak damdan yapılmış sıcak ağılda tutulur.

Kazaklar değerli misafirlere koyun kellesini ikram ederler. Kazakların "bas tartu" kelle ikram etme geleneği, bölgelere göre farklı özellikler içerir. Sır Derya bölgesinde misafir ağırlarken değerli kişiye kesilen koyunun alın kısmına dört yanımız eşit olsun niyetiyle "kaskaldaktap" yani alın kısmına çarpı gibi bir işaret konularak sunulur. "Kaskaldaktau' olarak adlandırılan bu gelenek, koyunun kellesine piştikten sonra çarpı gibi bir işaret koyarak yol açma geleneğidir (araştırmacıların gezi notlarından). Oğuzların seramik koyun taşlarının boyun kısmındaki dört yanım eşit olsun diye resmettikleri sembol, daha sonraları bu bölgelerde "kaskaldaktau" adını almış gibidir (Resim 17b).

Sır Derya bölgesinin aşağı akışı boyundaki Kazalı, Aral civarındaki Kazaklar konuklara kelle sunduklarında sağ kulağını kesip alıp ayırıp, onu kendi çocuklarının küçük olanına verirler ve misafire de kulaksız olarak sunarlar. Bu, rızkım, nasip olan kısmetim kendi evimde kalsın gibi niyetten doğmuştur. Sağ kulağın yerine incik kemiği koyarlar. Yani başın yanına kalça kemiği gibi kıymetli sayılan incik kemiği eklerler. Sır bölgesinin orta ve aşağı akışı boyundaki Kazaklar hangi hayvanın kellesi olursa olsun dişlerini temizledikten sonra pişirirler. Buralarda dişleri temizlenmemiş kelleyi pişirmek "haram" olarak sayılır. Sır bölgesinin geleneklere bağlı olan Kazakları diğer bölgelere gittiklerinde dişleri temizlenmemiş kelle sunarlarsa yemezler. Oysa Jetisu, Doğu, Moğolistan Kazakları, hayvanın kellesindeki dişleri temizlemeden pişirirler. Doğu Kazakları, kelleyi yiyecek misafir kellenin dişlerine bakarak hayvanın yaşını belirler düşüncesiyle hayvanın dişlerini temizlememeyi uygun görüyorlar (araştırmacıların gezi notlarından).

Kelle sunulmuş misafir öncelikle kendisi tadına bakar. "Kulağın iyi duysun ve dikkatli olsun" diye, sol kulağı çocuğuna ya da gelinine sunar. Gözlerini "Gözüm gibi ol" diye, yakın saydığı kimseye, damağını söz ustası olarak saydığı kimseye ya da sofrada oturan evin kızı veya gelinine sunar. Kafa derisini parçalar halinde herkese paylaştı- 
rır. $^{50}$ Kazaklarda, kelleyi babası hayatta olan insan ellemez diye, bir inanç vardır. Bu da büyüklere olan saygıyı ifade etmektedir. Baba hayattayken babadan büyükmüş gibi kelleye el sürmek edepsizlik olarak kabul edilir. Bu gelenek günümüzde de yaşatılmaktadir.

Sır bölgesinin Aral, Kazalı, Karakum bölgelerinde yaşayan Kazakların inançlarındaki bir başka özellik, Kurban bayramında kurban kesme sırasında hayvanın sağ bacağından evin sahibi tutmuş, bilek kısmından hanımı, hanımından sonra çoluk çocukları, gelinleri yan yana durarak birbiri ardından devam ettirerek tutmuşlardır. Evin sahibi "Çocuklarım nerede olurlarsa olsunlar sağ salim olsunlar, bizleri de peşlerinden sürüklesin, ayrılmasınlar" diye, dua edermiş. Hayvanın boğazından akan kanı, hayvanı boğazlayan kişi dizilmiş olan çoluk çocuğun alnına sürmüştür. Onlar, kan kuruyup kabuk bağlayana kadar yıkamamışlardır. Buritüel, adı geçen bölgenin köylerinde günümüze kadar yaşatılagelmiştir. Ev sahibi ise elindeki sağ bacağı keçe çadırın jelbau adlı parçasına bağlayıp, üç güne kadar bekletmiştir (araştırmacıların gezi notlarından). Onu da kurban bayramının üçüncü günü kullanmıştır. Bunlara, Kazak bozkırının diğer bölgelerinde olmayan özel ritüeller diyebiliyoruz.

Kazaklar arasında evcil hayvanların bazı kemiklerinin mucizevi özellikleriyle igili ilginç gelenekler, batıl inançlar ve efsaneler yaygınlaşmıştır. Kazak kışlıklarında ve keçe çadırlarının yanında yer alan hayvan ağıllarındaki develerin boynuna, inançlarına göre hayvanları kurtlarla hırsızlardan koruduğuna inanılan "kari jilik" adlı incik kemiğini asarlar. Böyle adetler aşağı Sır Derya, Üstürt ve Mangıstav bölgelerinde yaşayan Kazaklar arasında bugüne kadar yaşatılmaktadır.

İncik kemiğini diş değdirmeden, yani etlerini elle kopararak yerler. Koyunun kol kısmının dirsekten omuza kadar olan kısmında bulunan incik kemiğinin kamçısı, sırığı, ildirgisi (ipi tutmaya, asmaya uygun ilmeği bulunan çıkıntısı olan incik kemiği) olur. Kazana etler konulurken öncelikle incik kemiğini koyarlar. Bu da, hayvanın bütün etlerini incik kemiğinin bir arada tuttuğuna inanılan düşünceden doğmuştur. İncik kemiğini evde oturan kıza evde kalır evlenemezsin diye, yedirmezler. Buryatlar ve Türkmenler arasında incik kemiğini yabancı, tanınmayan kimseye sunarlar. Kazaklarda incik kemiğini aslında ihtiyarlar ile yaşı büyük kişiler kemirmiştir ve kemirdikten sonra canlılar (insanlarla hayvanlar anlamında) hayatta olsun diye eşiğe, hayvanları hırsızlardan korusun gibi inançtan dolayı eve veya ahıra asmışlardır. Kazak topraklarının Batı kısmında evin eşiğine incik kemi-

50 Demirci Hikmet - Bürkütbayeva Şınaray. "Kazak Misafirperverliği: Ülüş, Misafir Ağirlama ve Tabak Kültürü" Milli Folklor, 126 ( 2020), s. 202. 
ğiyle beraber okunmuş muska, kurt dişi, kartal tırnağı, bulaktas diye adlandırılan ortası delikli taşları, dağdan adlı ağacın dallarını birlikte asma adeti vardır. Bunların cinlerle perilerden, nazardan koruduğuna inanılmıştır. Bununla birlikte deve yavrusunun (köşeğinin) boynuna, hızlı koşan yllkının eyerlenmiş eyer takımının ön kısmına da incik kemiği asmak yaygındır (araştırmacıların gezi notlarından; Resim 20-22).

Halk arasında yaygın olan bir efsaneye göre, bir zengin kimsenin hayvanlarını kaçırmak isteyen hırsızlar hayvan sürüsünün etrafinda gezinen silahlı adamları görüp, gözlerine kestirdikleri hayvanları çalamazlar. Hırsızlar sürü sahibinin çobanlarının da, oğullarının da, kızlarının da olmadığını duyarak sürü sahibinin evine misafir olarak gelirler. Hayvanların sahibi bir koyununu keserek onları misafir eder. Hırsızlar da kendilerinin aslında ne amaçla geldiklerini açıklayarak: "Günlerdir takip etsek de hayvanlarınızı çalamadık, hayvanlarınızı silahlı adamların koruduğunu gördük. Aslında hayvanlarınızı kimse korumuyormuş. Bu işin sırrı nedir?" diye sormuşlar. O anda sürü sahibi, babam vefat ederken: "Koyun kestiğinde incik kemiğini atma. Onu kapıya, evin tavanına as. O zaman hayvanlarına kurt da, hırsız da yaklaşmaz" diye, bana vasiyet etmişti. Hırsızlar evin tavanına asılı olan incik kemiğine bakmış ve ne zaman incik kemikleri görürlerse o evin hayvanlarına yaklaşmamışlardır. ${ }^{51}$

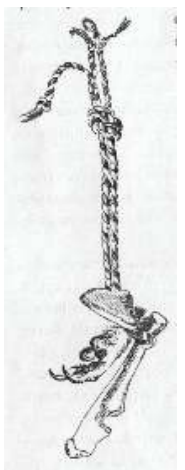

a

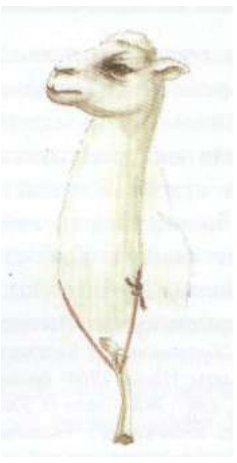

b

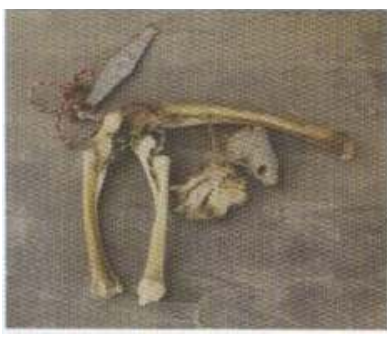

C

Resim 20: a. Muska şeklindeki incik kemiği; b. Deve yavrusunun boynuna nazardan koruması için asılmış olan incik kemiği; c. Ev muskasi, bulaktaşlarla birlikte asılmış olan incik kemiği. Batı Kazakistan. ${ }^{52}$

51 Valihanov, age., s. 63

52 Resim 20 - a) Rihard Karuts, Sredi kirgizov i turkmenov na Mangishlake, (Çev. E.Petri), Tipogfafiya A. 


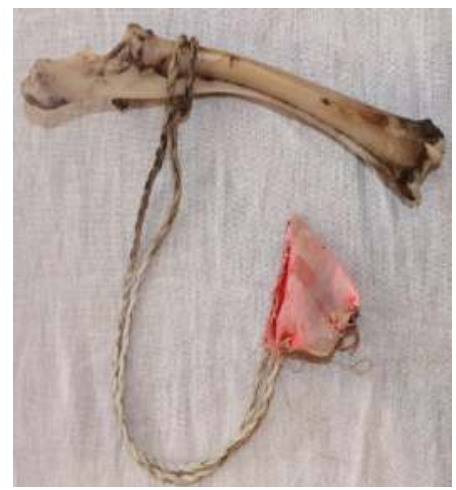

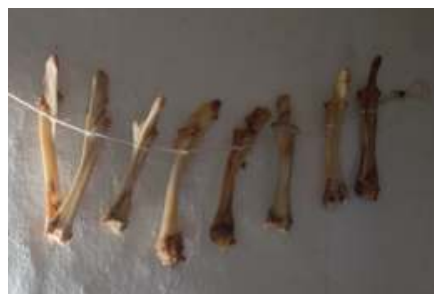

b

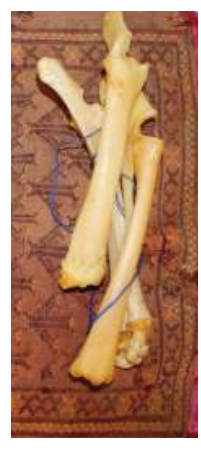

c

a

Resim 21: a. Okunmuş muskayla birlikte kapıya asılmış olan incik kemiği, Sır bölgesi, Aral; b. Bati bölgesi, Nurtas Safullin evindeki incik kemiği; c. Mangistau bölgesi, Başekeva Tiniştik evindeki incik kemiği ${ }^{53}$

İncik kemiğini kutsal yerlerden de skk sık karşlaştırmak mümkündür. Çünkü kutsal mekanlardan medet umarak gidenler hastalıklarından iyileşmek için şifa kaynağı ararlar. Bu da incik kemiğinin sihirli özelliğinin olduğuna olan inançtan kaynaklanmaktadir (Resim 22).

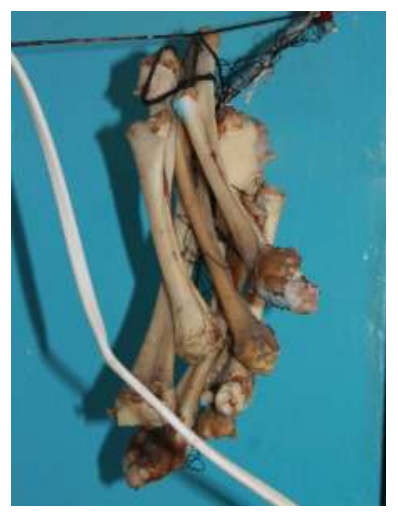

a

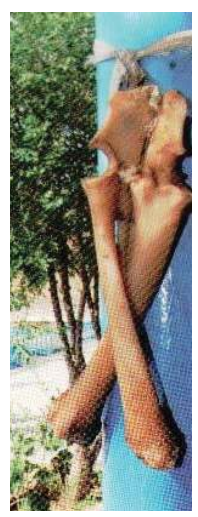

b

Resim 22: a. Sır bölgesi, Kojan Hoca Evliya türbedarının evindeki incik kemiği;

b. Mangıstau'daki Şopan Ata yeralt camisine asılmış olan incik kemiği. ${ }^{54}$

F. Devriyeva, Sankt-Peterburg 1910, s. 130; b, c) Alimbay vd, age., s. 130.

53 Resim 21 - Yazarlara ait fotoğraftur.

54 Resim 22 - Yazarlarra ait fotoğraftır.

Belleten, Aralık 2020, Cilt: 84/Sayı: 301; 907-958 
Eski dönemlerde üzerlik otunu koyunun derisine sararak eve asmışlardır. ${ }^{55} 1848$ yılında Kazak topraklarına gelip, Aral araştırmaları belgelerini toplayan Polonyalı araştırmacı Bronislaf Zalesskiy, kutsal ağaçların dallarına bağlanmış olan koyun derisinin parçalarını sıkça gördüğünü yazmıştır (Resim 23). ${ }^{56}$ Günümüzde kutsal sayılan ağaçların başına koyun derisi parçalarını asmak görülmese de, kumaşparçasını asmak oldukça yaygındır.

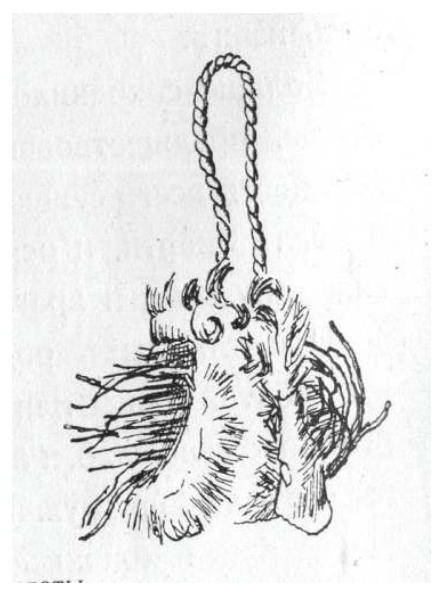

Resim 23: Üzerlik otu konularak asılmış olan koyun derisi. Mangıstau. ${ }^{57}$

Orta Asya ve Kazak halkının dünya görüşünde koyun derisi de totemlik açıdanönemli bir yere sahiptir. Eve yeni gelin geldiğinde ev sahibi gelini "Koyun yünü gibi yumuşak olsun" diye, koyun derisinin üzerine oturtmuştur. Bu gelenek Özbekler ile Karakalpaklar arasında da mevcuttur. ${ }^{58}$ Koyun, Romalılar arasında nikah ile aile bekçisi olarak kabul edilip, yeni evlileri Tanrı yolunda kurban edilmiş olan koyunun derisine oturtmuşlardır. Bunun yanı sıra Slavlar arsında da eskiden gençleri koyun ya da ayı derisine oturtmuşlardır. Oysa Hintliler arasında gençleri boğa derisine, Buryatlarda yılkı ya da hayvan derisine oturtmuşlardır. ${ }^{59}$

Karuts, age., s. 130.

Bronislav Zalesskii, Kazak saharasina sayahat, Oner, Almaty 1991, s. 69.

Karuts, age., s. 130.

Snesarev, age., s. 85.

Abdeş Toleubayev, Relikty doislamskih verovanï v semeinoi obriadnosti kazahov (XIX - nach. XX vv.), Gylym, Almaty 1991, s. 30. 
Koyun, keçi gibi küçük hayvanların kesimi sırasında kürek kemiğinin başındaki kıkırdağı kesilip alınıp, sıcak haliyle giriş kapısının üst tarafındaki dış duvara vurarak yapıştırılır ve onu kendiliğinden kuruyarak düşene kadar kimse bilerek düşermezdi. Bu da, atım yürük olsun ve eve gelen kimse temiz yüreğiyle, dürüstlügüyle gelsin gibi anlam taşımıştır (araştırmacıların gezi notlarından; Resim 24).
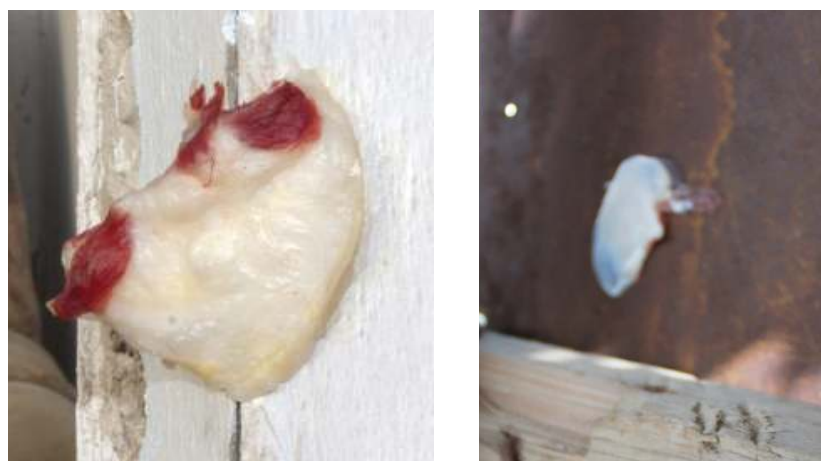

Resim 24: Duvara yapıştırılan koyunun kürek kemiğinin kıkırdağı. ${ }^{60}$

Kazak topraklarına gelen seyyahların kayıtlarına göre, eski dönemlerde kız geçirme düğünlerinde yeni evliler için özel olarak otağ (çadır) dikilmiştir. Damat, keçe çadırı kuran kadınlar için koyun ya da bir tayı otağ kapatma, moyuntastar olarak adlandırlan özel bir hediye olarak hazırlamıştr. Otak çadıra yeni evli gençlerle yengeleri toplandıktan sonra "moynntastar" (boyun firlatma) ritüeli yerine getirilmiştir. Damat ile gelin koyunun etinden tattıktan sonra yengelerinden biri koyunun kemirilmiş boyun omurgasını beyaz bir kumaşa sararak damada vermiştir. Damat da aşağı bakarak bu kemik parçasını keçe çadırın üzerindeki şanırak adı verilen delikten dışarıya atması gerekir. Bu ise "tütünü tüzu şısın" yani, evin içinde mutluluk olsun, ateşi sönmesin gibi batıl inanc1 bildirmektedir. Kazaklar "tütïnü tüzu şıksm" (dumanı düzgün yükselsin anl.) diye, evde hep sadece iyilik, sağık, mutluluk olsun anlamında söylerler. Kocası vefat etmiş kadının başka kimseyle evlenmemesini de "şanırağının tütünün tüzu şı̆̆arıp otır" yani, evinin huzurunu ve mutluluğunu korumaktadır anlamda kullanırlar.

Kazak halkı kadın doğum yaptığında kaljalasın (taze et yiyip, çorbasını içmek) diye, koyun keserler. Kalja için kesilmiş koyunun boyun etini kadına kemirttikten sonra, boyun omurgalarını 40 güne kadar asmıslardır. Kazak topraklarının doğusunda boyun kemiklerini atmadan saklamak ara sıra da olsa görülmektedir. 
Kızı evlendirme düğününde pişirilen etten koyunun orta incik kemiğini kızın annesi kadife kumaşa sarıp, onu müsse tartu için verir. Müsse tartu adlı oyuna kökpar (at üzerine yapılan yarış türü) yarışına katılan oyuncular gibi atının yeteneğini, yürüklügünü denemek isteyen delikanlılar katılır. Kemiği eliyle kapabilen kaçmaya başlar, diğerleri onun peşine takılıp, yakalamaya çalışrlar. Böylece kemik birkaç defa elden ele geçer. ${ }^{61}$

Kazaklar evlenmiş olan kızları kendi aile ve yakınlarını ziyarete geldiğinde koyunun kuyruk sokumu kemiğini, damat kız tarafina geldiğinde ise koyunun göğüs kısmını sunarlar. Göğüs kısmı en yağlı kemik parçasıysa kuyruk sokumu kemiği lezzetli kemiktir ve bunlar ritüel bir yiyecek olarak hayatlarının anlaml, bereketli olması amaciyla ikram edilir. Koyunun kuyruğu ile ciğeri de ritüel bir yiyecek türüdür. Dünürler birbirlerine verdikleri dünürlük yeminlerini kuyruk, ciğer yedirerek sağlamlaştırmıştır.

Koyun, keçi hayvanlarını ve koyunların geçici olarak bağlandıkları gerilmiş kalın urgan "kögen", hayvanların başının sokulduğu düğümlü kısımda "burşak" diye adlandırılır. Kögenin burş̧ăğ sadece yeni doğmuş hayvanlar için kullanılan bir alet değil, çoğalıp, gelişme düşüncesiyle ilgili büyülü bir karakter taşıyan, ritüel değeri var bir alettir. Kazaklar yeni evliler için dua ederken "kögenderin burşaktı bolsm" (urganların düğ̈̈mlü olsun) derler. Bu, çoluk çocuğun çok olsun anlamına gelen bir duadır. Çocuk sahibi olamayan kadınlar kögen burşağım (düğümlü urganı) boyunlarına asarak çocuk istemişlerdir. Doğum yapmakta olan kadın doğumunu gerçekleştirmekte zorlanıyorsa urgana birlikte kögene de tutunarak asılı kalmıştır. Bu, koyunlarlakeçilerin hızla çoğalmasıyla alakalıdır.

Kazaklar koyunlar yavruladıktan sonra kögen yağlamak, kögentüp, kögen toy gibi çeşitli adetleri yerine getirmiştir. Kögeni çeken adam akrabalarını, köy insanlarını kögen başına davet edip, adet gereği kögen ile onun kazığına yağ sürmüstür. Toplanan ihtiyarlar "kögenin uzun olsun, hayvanlannm yavrular çok olsun" diye, dua etmişlerdir. Yağ sürme işlemi, kuzularla oğlaklar çabuk büyüyüp, çoğalsın, rızık ile bereketten ayırmasın diye yapılmıştır. En yakınının çocuğuna ya da yiğenine (kızdan olma çocuğa) adet gereği bir hayvanı hediye etmişlerdir. $\mathrm{O}$ da kögendik ya da kögentüp diye adlandırılmiştır. ${ }^{62}$

Kazak halkında, "Bir kuzu fazladan doğarsa bir dip pelin otu fazladan yetişir", "Nice hayvanı olsa da zengin ikiz doğmasına sevinir " şeklindeki ifadeler, koyunun ikiz doğurmasının refah, üreme, bollukfikriyle bağlantısını ortaya koyar. ${ }^{63}$

61 Lubov Poltaraskaya, "Obychai kirgizov Semipalatinskoi oblasti”, Russkii Vestnik, 9 (1878), s. 22-69.

62 Alimbay vd, age., s. 278.

63 Bekarys Nurimanov - Amanzhol Altay, "Karacaoğlan ve Bukar Kalkamanuli’nin şïrlerinin kar- 
Eski dönemlerde Kazak topraklarının doğu bölgesinde dünyaya gelen erkek çocuğunun göbeğini kestiklerinde kesilen göbek parçasını koçun boynuzuna "maljandı bolsın" (hayvanları çok olsun) niyetiyle bağlamışlardır. Bazı aileler göbeği koyun aşık kemiğiyle beraber evin yanına gömmüşlerdir (araştırmacıların gezi notlarından).

Koyunun kürek kemiklerinin (jauırın) yardımıyla da gelecek hakkında yorumlarda bulunmuşlardır. Fala bakmak için kurban edilen kara koyunun kürek kemiklerinden alıp, onu diş değdirmeden yemişlerdir. Kürek kemiğine bakarak fal açmak Özbek, Karakalpak, Türkmenler arasında da görülmektedir. ${ }^{64}$

Keçe hazırlama zamanında bilekleme anında keçe yuvarlanırsa "koy bastı, koy bas$t \imath$ " derler. Burada keçeyi, yani yünü koyun olarak kabul etmek, bolluğun olacağına yorumlanır. Koyunun sonbahardaki yünlerini kırkma döneminden sonra ev sahibi "küzem şay" (kırkma çayı) vermiştir.

Koyunları kırkıp, yünlerini dövüp, keçe hazırladıkları sırada rüzgar esip, yünleri uçurtmaması için "kempirdin jağın baylau” (kocakarının çenesini bağlamak) adeti yerine getirlmiştir. Bunun için bir çocuk iki tane ince dalı ya da yetişmekte olan dalı yün iplikle bağlayarak, kocakarının çenesini bağladım diye bağırır. Keçe hazırlama sırasında dümdüz olarak ortaya çıkması için sarılmış kamışın ortasından urganla bağlayarak, urganın ucunu kendi tarafina çekip tutan kişiyi koybastar (koyunların başı) diye adlandırırlar. Bu adlandırma, keçenin koyun yününden yapılmasıyla alakalıdır. ${ }^{65}$

Koyun, koç gibi kelimeler, özel bir sihirli güce sahip olmuştur. Kazak ve Türk soylu halklar doğan bebeğe isim verecekleri sırada iyiliğe yormuşlardır ve belli bir amaç doğrultusunda hareket etmişlerdir. Koylıbay, Koşkarbay, Kozı Korpeş, Kozıbay diye isim takarak çocuğun bolluk içinde yaşamasını istemişlerdir.

Ramazan ayında Kazaklar Jarapazan (Ramazan ayında ev ev dolaşarak belirli bir ritimde ve melodide söylenen şiirler) söylediklerinde:

"Kuzularn atası

Koçlar bassin evini"

ya da

şilaştirilmasi”, Milli Folklor, 117 (2018), s. 46.

64 Snesarev, age., s. 115-116.

65 Alimbay vd, age., s. 699.

Belleten, Aralık 2020, Cilt: 84/Sayı: 301; 907-958 


\section{"Farapazan söyleyerek geldim kapina}

Koç gibi çift oğul versin beșiğine

Koç gibi çift oğul verse beşiğine

Kimler gelip, kimler gitmez kapına" demişlerdir (araştırmacıların gezi notlarından). Erkek evladına evin sahibidir diye, Kazak halkı "koşkarday" (koç gibi) benzetmesini söylemiştir. Şiirdeki "Kimler gelip, kimler gitmez kapına" satırlarının anlamı, oğlun olursa evinden misafir eksik olmaz, misafir uğurdur demektir.

Sır Derya Kazakları günümüzde de hayvan sürüsünün önünü kesmez. Hızır Ata'nın sürüyle beraber dolaştığına inanırlar.

Kırgizlarda evlenme sırasında oynanan oyunlardan biri, sadaga çapkan diye adlandırılır. Bu oyunda damat ile gelin hanım yan yana oturtulup, başlarına örtü örtülür. Daha sonra başlarını yavaşça yeni kesilmiş ve derisiyüzülmüş oğlakla ya da yeni kesilmiş koyunun akciğerleriyledöverler. Bu ritüel sona erdikten sonra damatla gelin otak eve doğru koşarlar. Birinci olarak kim ulaşırsa yeni kurulmakta olan yuvayı da o yönetir diye inanılır. ${ }^{66} \mathrm{Bu}$, kuzu ve oğlaklar gibi kısa zamanda çoğalırlar inancıyla alakalıdır.

Alman araştırmacısı Rihart Karuts, Kazakların tanınmış bilim adamlarının başlarına koç boynuzunu koyduklarını yazar. ${ }^{67}$ Koç boynuzunun evliyaların baş ucuna konulması, önemli bir anlamtaşımıştır. Oysa dağlık ve taşlık bölgelerde, yani dağ koyunlarının mekan ettikleri yerlerde dağ koyunu boynuzları önemli bir rol oynamıştır. Sır Derya'nın orta akışı kısmındaki kavimler dağ koyununu Karatau'ın batı tepelerinden avlamışlardır. Iosif Kastaniye'nin sunduğu krokilerle resimlerde Kamakşı topraklarındaki Şekeniyaz, Janakorgan'daki Sunak Ata türbelerinin ön kısmına dağ koyununun baş kemiği ve koç boynuzu konulmuştur ${ }^{68}$ (Resim 25 a, b). Günümüzde mezar başına koç başını koymazlar, fakat Şiyeli, Janakorgan bölgelerindeki eski mezarlıklarda ünlü kişilerin mezarlarının başına dağ koyununun baş kemiğini (kellesini) koyma geleneği korunmuştur (Resim 25 c, d). Dağ koyunu, sadece aziz ve evliya kimselerin kabirlerinin başına konulmuştur. Bu ise sadece tanınmış evliyaların hürmetine kesilen

Gennadi Simakov, Obşsestvennye funksii kirgizskih narodnyh razulecçenii v konse 19 - naçale 20 v. Leningrad: Nauka. 1984, s. 153.

67 Karuts, age., s. 122.

68 Iosif Kastaniye, Nadgrobnye sooruzhenija kirgizskih stepei. Orenburg: Tipografiya Turgaiskogo Oblastnogo upravleniya. 1911, s. 47, 53-54; Iosif Kastaniye, Poezdka po Turgaiskoi i Syr-Dar'inskoi oblasti, 1906 - 1907 g. Vdol' Taşkentskoi zheleznoi dorogi. Tipografiya G.M. Mil’berg, Orenburg 1909, s. 11. 
kurbanın işareti değil, boynuzlu hayvan başını kabir başına yerleştirme gibi arkaik bir geleneğin olduğunu da ortaya koymaktadır. Türbelerle mezarlıklardaki "koyun, koç, dağ koyunu kültü', Sır bölgesini mekan eden eski kavimlerin dini dünya görüşlerinin devamı niteliğini taşımaktadır diyebilmekteyiz.

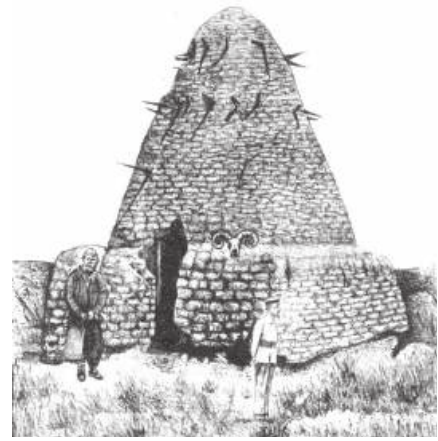

a

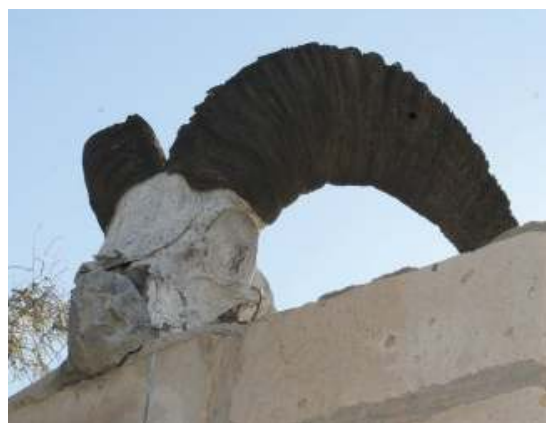

c

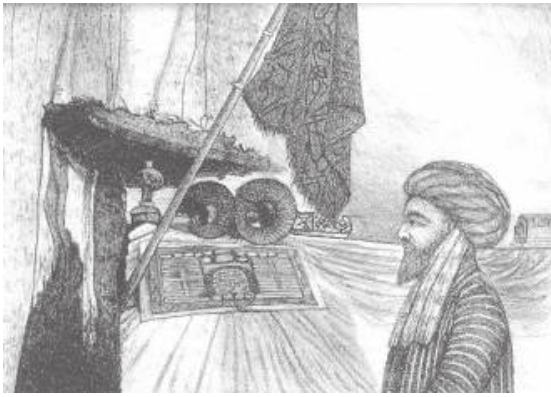

b

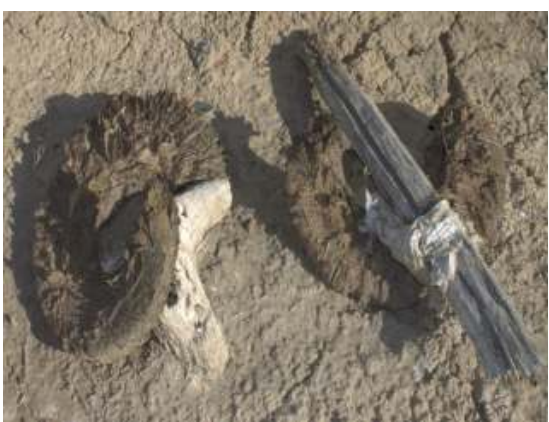

d

Resim 25: Sır bölgesindeki mezar başındagi koç ve dağ koyununun baş kemiğleri;

a. Şekeniyaz türbeleri; b. Sunak Ata türbeleri ${ }^{69}$ c-d. Şiyeli, TaraktilarMezarlı̆ğ ${ }^{70}$

Eski dönemlerde Özbekler ile Karakalpaklar, koç boynuzunu talisman olarak evin girişine asmışlar, kadınlar ile kızların başlıklarını koç boynuzu şeklindeki ağaç tabakalarla süslemişler. Koç boynuzu şeklindeki boyuna takılan süsler de olmuştur. ${ }^{71}$ Azerbaycanlıların da halk bilimi sisteminde hayvan kafatasını ağaca asma inancı yaşa-

69 Kastaniye, age., 1911: tablo XVI, XXI.

70 Resim 25 c, d - Yazarlara ait fotoğraftır.

71 Snesarev, age., s. 115-116. 
tilmaktadır. $^{72}$

Kazak halkının inanç sistemi dört tülük hayvanla (dört çeşit besin hayvanıyla) yakından ilgili olup, selam verdiklerinde bile "mal-jan aman ba" (hayvanlarla canl-lar să̆ salim mi) diye hal hatır sormuşlardır. Hayvanlara zarar gelmesin, sayısı azalmasin niyetiyle eski Kazak geleneklerinin hâkim olduğu bölgelerde günümüze kadar totem olarak kabul edilen hayvanlarla canlıların kemiklerini ahıra, çitlere asma, koruyup saklama adetleri sürdürülmektedir (Araştırmacıların gezi notlarindan).

Eski dönemlerde koyunun "bagalşak" diye adlandırılan ayak parmağı kemiklerinden çocuklar için "zınldawık" adlı oyuncaklar hazırlamışlardır. İki bagalşak kemiği birbirine deve yününden eğrilen "şuda" diye adlandırılan iple bağlayıp elle iyice bükerek döndürmüşlerdir ve serbest bıraktıklarında çıngırak sesine benzer bir ses duyulmuştur. Günümüzde bu oyun kaybolmuştur. Bizler bu oyunu yeniden canlandırmak ve kültürümüze kazandırmak amacıyla Mangıstau bölgesinde kendimiz organize ettik (Resim 26).

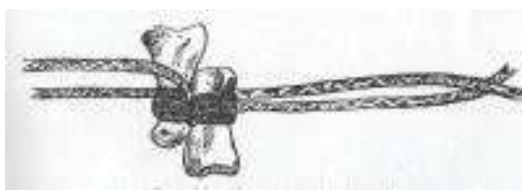

$\mathbf{a}$

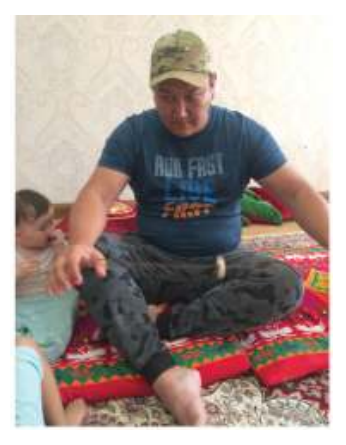

C

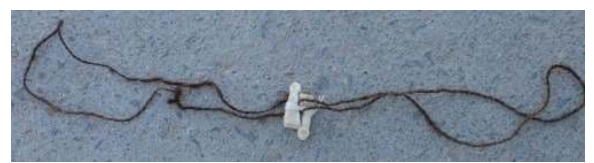

b

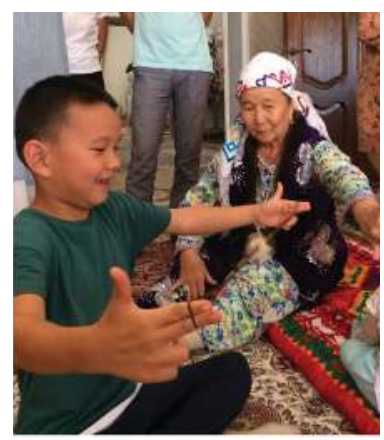

d

Resim 26: Zyryldauk Çocuklar oyunu. ${ }^{73}$

72 Yaşar Kalafat, Kars'ta Gregoryen türkler ve mezar mimarileri - Ak ve Kara Koyunlu Mezar Taşlarmın Çizdiği Tarihî-Coğrafi Kültürün Sintrlan, http://www.yasarkalafat.info/kalafat.info/dosyalar/kalafat2014151920.pdf (Erişim: 27 Kasım 2016).

73 Resim 26 - a) Karuts, age., s. 89; b, c, d) Yazarların yaptığı Zyryldaukla adlı oyuncağın bir çocuğa 
Koyunun kulağına bir çizgi, işaret (damga) koymak, kabile mülkiyetini, koyun sürülerinin hangi kabileye, kime ait olduğunu göstermek için yapılmıştır. Koyunu işaretleme geleneği de Türk halklarına ortaktır. ${ }^{74}$

\section{Koç ve Kurbanlık Hayvan}

Halk arasındaki efsanelere ve inanışlara göre koç, gökyüzüyle ateşten, at rüzgardan, deve çölden, boynuzlu hayvanlar sudan, dağ keçisi taştan yaratılmış. ${ }^{75}$

Kurban hayvanı olarak koçun çakra anlamı, Gök Tanrı, gökyüzü ile insanoğlunu ilişkilendirme ve aralarında bağlantı kurma çalışmalarıyla ilgilidir.

Türk soylu halkların inançlarına göre koç, hem koruyucu hem de kurban edilebilecek hayvan niteliğindedir. Onlar Kazak ve Kırgız halklarının geleneksel inançlarıyla ilgili törenlerinde kullanılmıştır.

Sır bölgesi Kazaklarının doğanın gücüne olan inançlarından antik çağın mitolojik, animist inançlarına sahip olduklarını doğal afetlere karşı, kuraklık yaşanmasın diye koyunu kurban edip, sadaka, "tasattık” (hayır yemeği) vermelerinden görmek mümkündür. Kurban edilen koyunun başını sırık başına asıp ekin arazilerine yerleştirme, kanını da ekin bölgesine püskürtme geleneği ve kurban edilecek hayvanı ekin alanına su ulaştıracak kanalın başına getirip kurban edip, kanını da suya akıtma geleneği ekinleri kuraklıktan korumak amacıyla gerçekleştirilmiştir (Resim 27). "Tasattık" yani hayır yemeği de baharda dağıtılmıştır. "Tasattık" (hayır yemeği), hayvanın yiyeceği otunun bol ve hayvanların da semiz olması için verilir.

oynattırılması. Yazarlara ait fotoğraftır.

74 Tuncer Gülensoy, Damgalar, s. 18.

75 Grigori Potanin, Ocherki Severo-Zapadnoj Mongolii, Vyp II. Materialy etnograficheskie, Sankt-Peterburg 1881, s. 152-153. 


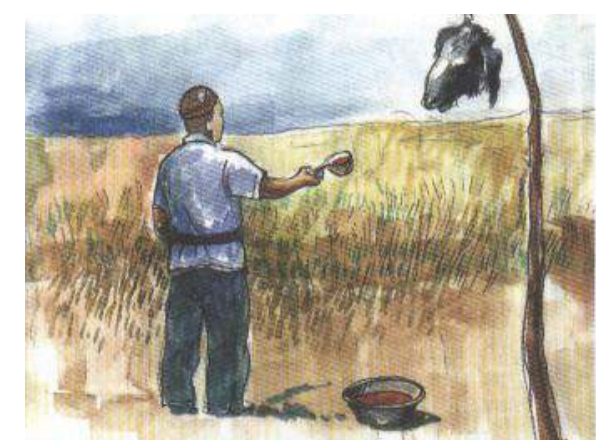

Resim 27: "Tasattık" hayır yemeği için kurban edilen koyunun başı.

Dini mitolojiye göre koyun Mekke'den türemiştir. Koyun sürüsüne şarbon hastalığ1 yayılıp, koyunlar ölmeye başlayınca ölen koyunların başını Mekke'ye çevirerek gömmüşler. Sürü sahibi yakın akrabasından hastalıksız koyunu getirerek kurben edip, kanını da başka koyunlara sürüp, başını sııı̆a asmıştır (Resim 28). Hayvan sürüsünü de mezarlık başına götürüp geceletmiştir. Böylece sürüyü sarmış olan bulaşıcı hastalıkla sıradışı çözümlerle savaşmaya çalışmışlardır.

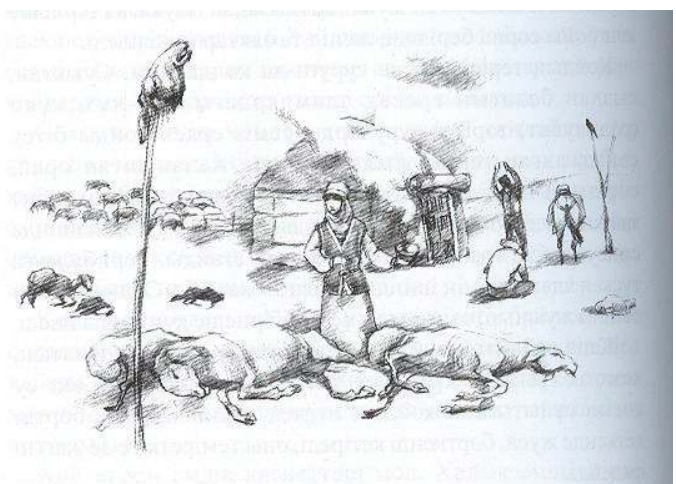

Resim 28: Koyun sürüsünü bulaşıcı hastalıktan kurtarmak için asılmış olan kurbanlık koyun baş1. ${ }^{76}$

"Dede Korkut' kitabındaki "Dirse Han Oğlu Boğaç Han hakkındaki destanda" Dirse Han Allah'tan çocuk isteyip, attan aygir, deveden buğra, koyundan koç kurban edip, aç görse doyurup, çılak görse giydirip, borçluyu borcundan kurtarıp, düğ̈n yapıp 
dilek diler. Dileği Yaradan tarafindan kabul görülüp, Oğlan adlı erkek çocuğu dünyaya gelir. Erken dönemlerde Oğuzlar, 15 yaşa gelen oğullarını yırtıcı kuşla avlanmaya, av avlamaya götürmüşlerdir. İlk ava çıkışıdır diye, anası attan aygır, deveden buğra, koyundan koç kesip düğün yapmıştır. Bu da avcılığın yolunu açmak olarak yorumlanmiştır. $^{77}$

Kurbanlık kesip, dilek dilemek nesilden nesile ulaştırılan gelenektir. Çocuk isteyen Kazak kadınları evliyaların kabrini ziyaret edip, kurban kesip, orada geceleyerek dilek dilemişlerdir. "Alpamıs Batır" destanında Alpamıs’n anası Alpamıs gibi erkek çocuğu doğurmadan evvel kutsal dağ, su ve ormanlarda geceleyerek, aygır, koç kurban edip, Allah’tan çocuk dilemiştir. "Şora Batır” destanında da buğra, aygır, öküz, koç kurban ederek Yaradan'dan çocuk istedikleri görülür.

Evliya kabrine, kutsal yerlere gidip tevbe etmek, gecelemek, evliyalardan yardım ummak Kazak halkının dünya görüşünde eskiden beri vardır. $\mathrm{O}$ antik animizm ile tanrıcılığın parçalarıdır, yani antik politeizmden monoteizme geçiş çağının kalıntısı olarak günümüze kadar korunmuştur. Kazak halkının eski dönemlerdeki dünya görüşünün bazı işaretleri İslam dinini kabul edip, yeni dünya görüşleriyle karıştıkça evliya kavramının içeriği de zaman geçtikçe zenginleşip gelişmiştir. Anemizm, yaşam sahiplerinin öteki dünyada da bir başka hayatın var olduğuna olan inançlarıve onlarla insanların irtibat kurabilme imkânlarının olduğu hakkındaki kavramdır. Yani insanların ruhi varlıklara inanıp, ruhlara değer vermeleri, ölümü hayatın öteki dünyadaki devamı olarak kabul etmeleridir. Eski dini inançlara göre kurban edilen hayvanı ve onun kemiklerini ahiretteki yoldaşı olarak birliktegömmüşken daha sonraki dünya görüşlerine göre kurban edilen hayvan aracılığıyla çakra iletişimkurulduğuna inanılır.

Kurbanlık koyunların rengi de büyülü anlamlar içermektedir. Eski zamanki inançları esas alan kurban kesme geleneğinin bozkaska, kökkaska, kızılkaska hayvan kurban etmek gibi üç çeşidi vardır. Buradaki bozkaska koyun, kökkaska yılkı, kızılkaska inekle ilgili renklerdir. Eski dönemlerdeki Kazaklar kurban kestiklerinde çok nadir olan aksarı baş ya da boz kaska renkli olanını kesmeye özen göstermişlerdir. Boz kaskanın Tanrı'ya dileklerini daha çabuk ulaştırdığına inanılmıştır. Boz, kök (mavi) renkleri ilkel Kazakların sığındığıTanrı’nın, gökyüzünün sembolü olarak sayılan kutsal bir renk olarak görülmüştür. Kurbanlık koyunun renginin ak, ak çizgili, başında ak işaretinin olmasını iyiliğe yormuşlardır. İyilik yolunda kurbanlık hayvan adamayı "aksarbas" (ak+sarı+baş) diye adlandırırlar. Uzak yolculuğa çıkmış bir insanın sağ salim dönmesi için 
kurban olarak adadıkları koyunu mecazi şekille "A, Yaradan, yolunu hayırlı et, bu yol için aksarbas adadım” demişlerdir. İlkel Kazaklar arasında aksarbas kurban ederken "O ruhlar, size ayboynuzluyu adadım" diye sıkça söyledikleri olmuştur. ${ }^{78}$ Koyun ve özellikle beyaz koç eski Türklerde Gök Tanrı'ya sunulan kurbanlar arasındaydı. ${ }^{79}$ Sır bölgesinin Kazakları çocuk hastalıkları uzun sürdüğünde, hastalık koyunun kanına geçer inancıyla babası kara koyunu kurban edip "bu koyun benim evladımın yoluna kurban olsun" demişlerdir. Burada dikkat çeken, "dert geçirme" (hastalığ1 başka bir şeye taşıma anl.) geleneğinin baksıların teşrifinsiz de yapılmış olduğu ve kurban olarak da kara koyunun kesilmesi hususudur. "Dede Korkut" kitabındaki, "Dirse Han Oğlu Boğaç Han” hakkındaki destanda Bayındır Han düğün yaptığında Dirse Han’ı oğlu kızı yok diye, altına kara keçeyi serip, kara koyunun etini vermiştir. ${ }^{80}$

Kurbanlık hayvanların renginin çakra anlamı olmuştur. Eski Türk dilinde ak, kara kelimeleri sadece rengi bildirmekle kalmamış, ayrıca belli bir anlama da sahip olmuştur. Ak renk açıklı̆̆ın, mutluluk ile sevincin rengidir. Mesela, "gönlü ak" dedikleri ruhun temizliğini bildirmiştir, otun kalitesine göre "ak ot", "ağzı aka kavuştu” demişler. Sarı kelimesi Türk ve Moğol dilinde sarı "net”, "açık”, "belirgin”, eski Fars dilindeki sar "önemli", "esas", Türk dillerindeki sar "geniş", "1ssız" gibi anlamlar ifade ettiyse günümüzdeki Kazak dilindeki sarı kelimesi "geniş”, "büyük", "devasa" anlamını taşımaktadır. Moralin bozuk olmasını "gönlüm kara", yanılmayı "kara bastı", kaygılanmayı "karalara bürünmüşüm” demişlerse, insanla ilgili kara kelimesi "karası belirdi", "kalın kara", "koruyucum olan kara ormanım”, Dede Korkut Boğaç’a dua ettiğinde "Kara dağın yıkılmasın” demiştir. Yani, ak, aksarı koyun sevinçli durumlara, kara koyun gönül huzursuz olduğunda kurban edilmiştir.

\section{Halk Tıp Bilimleri Sisteminde Koyunun Önemi}

Yeni doğan bebeği kırkından çıkarana kadar ovup masaj yaptıklarında koyun kuyruğunun "küntimes" (güneş görmeyen) diye adlandırılan iç kısmının yağını ateşte eritip, kavurduktan sonra yağlamışlardır. Koyunun kuyruk yağını yakıp, soğuk değmiş insa-

78 Valihanov, age., s. 56; Argynbayev, age., s. 187.

79 Yaşar Çoruhlu, Türk Mitolojisinin Ana Hatlar, s. 150-151; “Türk Sanatı'nda Koyun, Koç, Keçi Figürlerinin Sembolizmi”, Türk Dünyası Tarih Dergisi, 100 (1995), s. 55; "At ve Koç/Koyun Şekilli Mezar Taşlarının Sembolizmi”, Toplumsal Tarih, 94 (2000), s. 35-42.

80 Korkyt Ata enciklopedialuk jinak, s. 130. 
na da içirtmişlerdir ve koyunun kızdırılmış yağını özellikle üşüterek hastalanmış olan çocukların tedavisinde kullanmışlardır.

Terlemenin eski Kazaklar arasındaki en yaygın türü, deriye sarmaktır. Bu, hayvancılı̆̆ın gelişmesiyle, hayvanların da çokluğuyla alakalıdır ve bunun çok fazla kargaşası, işi olmamıştır. Bu amaç için koyun veya keçi derisi bütünüyle sıyrılarak, onun içine hasta kişi oturduğu haliyle sığar olmuştur. Sıcak deriye sarılmış olan kişi terleyip, hatta uykuya bile dalarmış. Deriye sarılma işlemini gün aşırı, iki defa tekrar etmişlerdir. Çünkü, taze deri hastayı çok terletip, zayıf düşürürmüş. A. Başmanov, deriye sarılma işleminin Oğuz kavimleri arasında geniş bir biçimde yer aldığını yazmıştır. ${ }^{81}$ Oğuz kavminin eski mekânının Sır Derya'nın aşağı akışı civarı olduğunu dikkate alırsak, "deriye sarıp terletme" Sır halklarının arasındaki eski ve ilkel tedavi edici yöntem olarak bilinir.

M. Lialina'nın 1894 yılındaki yazılarından halk hekimleriyle ve üfürükçülerin hastaları nasıl tedavi edip iyileştirdikleri hakkında birçok bilgiye sahip olmak mümkündür. Orada, "kökjötel (boğmaca), titreme, ateş yükselme gibi rahatsızlıklar, pirinç yetiştiriciliği ile uğraşan yerlerde daha fazla görülmektedir" denilmiştir. Elbette burada yazarın Sır bölgesinden bahsettiği tartışlmaz gerçektir. "Yerel halk hekimleri boğmacaya bitki özleri ile demlenmiş içecekler içiriyorlar. Bu tedavi şekline cevap vermezse yeni kesilmiş yılkının derisine sararlar. Derini sık sık değiştirmeye çalışıyorlar. Bu da yardım etmezse Allah yolunda kurban olarak ak koyun kesip, kesmeden evvel koyunu yürüterek hasta kişiyi üç defa etrafinda döndürerek "işte, sana can için can, hastaya hayat ver" diye, söylerler" ${ }^{82}$ Yani, boğmacaya yukarıda adı geçen deriye sarma işlemini uygulamışlardır. Yazarın "deriyi sık sık değiştiriyorlar” diye ilettiği bilgiler, dikkat çekicidir. $\mathrm{Bu}$, öncelikle deriye sarmak için özel olarak birkaç hayvan kesmesi ve hastalığa şifa arayan halkın "terletme işleminden" iyileşmeye ümit artması demektir. Daha sonra, hasta için birkaç hayvan kesilmese de konuklar için, yemek için kesilen hayvan derisini hastalıkları tedavi etmek için kullanmışlardır diye kanaat getirmekteyiz.

Sır bölgesinde ün kazanmış Ali Aydar adlı üfürükçü, soğuk algınlı̆̆ı ile sancıları tedavi etmek için bütün olan koyun derisine sıcakken samboğa, bozboğa adlı otları koyup, hastayı koyun derisinin içine oturtup, deriyi de boyun kısmından büzerek bağlamıştır. Çiç̧ek hastalığına yakalanan çocuğu tedavi etmek için kara koyunu kurban edip, onun derisine sarma yöntemini uygulamıstır. Deriye sarmanın en önemliamacı hastayı terletip,

81 A. Başmanov, "Pervobytnaja istorija turecko-mongol'skih plemen”, Turkestanskiye Vedomosti, 49 (1914), s. 4-5.

82 M. Lialina, Puteshestvie po Turkestanu N.Severcova i A.Fed-chenko, Sankt-Piterburg, Izdanie A. F. Devrieva. 1894, s. 102. 
vücuttaki çeşitli enfeksiyonları dışarı çıkartmaktır. Kazakistan'ın Doğu bölgelerinde meşhür olan baksı Mauthanoğlu Arıngazı, sıcak suya demlenmiş çeşitli bitkisel otları bütün olarak kesilmiş koyun derisine serpiştirip, çocuğu olmayan kadını içine oturtmuştur. İç yağlarını kadının altına ve karnına bağlamıştır. Terletmek için sık sık çorba (kaynamış et suyu) içirtmiştir. Kadının boyundaki hastalıklarla zararlı şeyler deriye geçermiş. Tedavi seansı sona erdikten sonra deriyi köyün dışına götürüp gömmüşlerdir. ${ }^{83}$ Kuyan (eklem hastalıkları) ve kurna (karının soğuktan sanclanarak ağrıması) hastalıklarını tedavi etmek için kullanılan terletmenin eskişeklini Abubakir Divayev kayda geçirmiştir. Bunun için çeşitli hayvanların kemiklerini (koyun kemiği de vardır) toplayıp, onları bir çukura koyduktan sonra hastayı oraya yatırıp, üzerine koyun derisini örtmüşlerdir. Hasta olan yerine sıcak pilav basip, ssitiyor. Bu sırada hasta da terleyerek uykuya dalar. ... Kırna hastalı̆ını tedavi etmek için ocaktan sıcak külü alıp, seramik çaydanlığın içine koyup, havluyla sarıp, hastanın karnına basmışlardır ya dakarakeçiyi kesip, akciğerini kalbiyle beraber çekip çıartıp, llk haliyle hastanın çıplak vücudunu onunla uzun bür süre dövmüştür. Hasta da terledikten sonra iyileşmeye başlamıştı. ${ }^{84}$

P. Paşino, Kazalı bölgesi Kazakları arasında yeni kesilmiş koyun derisine sarılmak, hasta olan yere koyunun iç organlarını basıp, sarılarak yatma şeklinin yaygın olduğunu yazmışıı. ${ }^{85}$ P. Paşino'nun deriye sarılmanın Kazalı Kazakları arasında yaygın olduğunu bildirmesi, A. Başmanov'un verilerini kesinleştirmeye temel olacaktır. Kazall, eski Oğuzların mekânıdır. Jankent, Jent şehirleri Sır civarının Kazalı bölgesinde yer almaktadir.

Sır bölgesinde yaşatılan terletme yönteminin bir başka özel türü, karna dïşmektir. Bu yöntemi gebe kalamayan kadınları tedavi etmek için kullanmışlardır. Onu gerçekleştirmek için yeni kesilen koyunun karnına sıcak halde kadının iki ayağını koydurup, üzerinden yorğan ya da çapanla sıkı sıkıya kapatarak terletmişlerdir. Elbette, terletebilmek için de ek olarak sıcak çay vermişlerdir. Halk hekimliğinde gebelik eğitiminin özgünlügünü ortaya koyan terletmenin bu türleri günümüze doğru kullanılmamaya başlamıştır.

Kazak şamanlar hastaları tedavi ederken belli bir zaman içerisinde olumlu netice alınmadıysa hastalı̆̆ "taşıma" ritüelini yerine getirmişlerdir. Delirmiş ya da cin çarpmış olan hastanın hastalığını taşımak için şaman hastanı yanına alıp, koştur-

83 Toleubayev, age., s. 30.

84 Abubakir Divayev, "Kirgizskie bolezni i sposoby ih lecheniya", Turkestanskiye Vedomosti 80 (1902), s. 482.

85 P. Paşino, Turkestanskii kraiv 1866 godu, Putebıe zametki, Sankt-Piterburg. 1868, s. 26. 
tuyor ve onun çevresinde dönerek "Hu, hu, Allah hu!” diye yüksek sesle bağırırmış. Bu tedavi üç günden bir aya kadar sürermiş. Yapılan tedavi yöntemi netice vermeye başlarsa, koçtan kurban keserlermiş. Kesilen hayvanın derisine hayvanın kemiklerini toplarmış. Yanına bu kemiklerin olduğu deriyi ve hastayı alıp iki yolun kesiştiği kavşağa ya da açık bir alana getirip hastayı okuyup üflermiş. Bazı şamanlar kesilen malın baş kemiğini siyah, kırmızı renklere boyarlarmış. Boyadığı baş kemiğini hastanın altınan geçirerek uzağa firlatırlarmış. Bu arada hastanın içindeki kötü niyetli ruhlar o baş kemiğe doğru atılıp, onu kemirmeye başladığı sırada şaman hastayı kaçırırmış. ${ }^{86}$ Kazak topraklarının batı tarafinda ise şaman, derinin içerisine konmuş ve boyanmış kemikleri batıya doğru firlatırmış. ${ }^{87}$

Şamanların hastalıkları taşıma yönteminin bir başka şeklini Kastaniye göstermiştir. Bunun için başında özel işareti var sarı keçiyi ya da kara koyunu kesip, etini kemiklerinden ayırıp, kemiklerini deriye sarıyor ve etini pişirip "Allah için" diyerek halka dağıtırmış. Şaman ile hasta bu etten yemezmiş. Şaman deriye sarılmış kemikleri ve hastayı yanına alarak büyük bir yolun kıyısına götürürmüş. Yolun kıyısında şaman çukur kazarmış ve hastayı o çukura yatırıp üç defa ileri geri hareket ettirirmiş. Ardından, deriyle kemikleri orada bırakıp, hastayı alıp evine dönermiş. Iosif Kastaniye'ye göre hastalığı taşıma ritüeline Nikolai Ostroumov (Rus oryantalist) da tanık olmuş. Perovsk şehrinin yakınlarındaki yol kenarından geçerken kavşaktaki kumlu tepelerin arasındaki çeşitli eşyaları fark etmiş ve yakından bakmak istemiş. Yol arkadaşı bu eşyalara yaklaşmaması gerektiğini, hatta hiç bakmamasını tavsiye etmiş ve o eşyalara hastalıkların taşınmış olduğunu söylemiş. Yol arkadaşının şiddetle karşı çıkması ve bakmayı yasaklaması, Ostroumov'u daha da meraklandırmış. Nikolai Ostroumov, yerde yedi kukla ile koyun derisini görmüş ve arkadaşı da yedi kuklanın yedi düşmanı kastettiğini söylemiş. ${ }^{88}$

Erken dönemlerde Kazaklar şarbon hastalı̆̆ını hisseder hissetmez çiviyi ya da demiri kızdırıp, yaraya basıp yarayı yakmışlardır. Eğer ilerlemişse tehlikeli hastalıkları tedavi etmek için baksı koyunun kurutulmuş kırk dışkısını alıp, hastanın karŞısına oturup, derin derin nefes alıp, elindeki dışkıların birisini hastaya doğru atar. Aynı anda Arbay adlı şairin ezgisini de söyleyerek kırk dışkı bitene kadar teker

86 Petr Komarov, "Poveriya kirgizov”, Turkestanskiye Vedomosti, 150 (1905), s. 790.

87 Petr Simon Pallas, Puteshestviye po raznum provintsiyam Rossiskoy imperiyi. P.1. Putishestviye 17681769 y.y. Translation of O. Tomsky, Tipog. Imp. ASc., Sankt-Peterburg 1773, s. 577.

88 Iosif Kastaniye, "Iz oblasti kirgizskih verovaniyi”, Vestnik Orenburskogo Uchebnogo Okruga, (1913), s. 152-153. 
teker atar. ${ }^{89}$ Dışkıları alırken de "Hey, kendinden başkasına şifa ol" gibi ifade kullanır. Göbeği dışına firlamış olan çocuğun göbeğine koyunun ya da devenin de dışkısını getirip basarlarmış.

Yukarıdaki bilgiler, Türk halklarının Halk Bilimi sisteminde insanın dünyaya geldiği günden öldüğü güne kadarki yaşatılan bütün gelenek göreneklerle ritüellerinde koyun ile koçun önemli bir yere sahip olduğunu göstermektedir.

\section{Koç Boynuzu ve Millî Nakış}

Koç boynuzu (koşkarmüyüz) şeklindeki süsleme resimler, çeşitli halı desenlerinde, keçeden yapılmış malzemelerde, nakışlarda yer alıp, bereketi ve zenginliği sembolize eder. "Koşkar müyüz"(Koç boynuzu), "Kanath koşkar müyüz”"(kanatlı koç boynuzu), "smık koşkar müyüz”" (kırık koç boynuzu), "smar koşkar müyüz” (çift koç boynuzu) nakış süslemelerinin günlük yaşamda kullanılan eşyalarda resmedilmesi, antik kalıntıların çakra modelidir.

Kazak halkının anlayış biçiminde koç boynuzu şekli, bütünnakışların atası ve bolluğun, zenginliğin işareti olarak kabul görülür.

Arkeolog bilim adamlarının bir kısmıkoç boynuzu şekli koç, koyun görüntülerinin zoomorfik şekle dönüşmüş görüntüsüdür, bir kısmı da insan görüntüsünü resmetmekten oluşmuştur derler. Orta Asırlık Otırar şehrinden bulunan tunçtan yapılmış mumluğun alt kısmındaki koç boynuzuşekli, Tunç Çağı'ndaki petrogliflerdeki insan şekli ile Saka'ların altın kalıplarındaki insan şekline benzemektedir. Sır boyunun aşağı akışının boyuna yerleşmiş Kesken Küyük şehri vardır. Küyük şehrinden M.S. 5-7. yüzylllara ait olduğu sanılan, Jankent'ten bulunan 9-11. yüzyllara ait olduğu bilinen seramiklerde koç boynuzu şeklinin birkaç çeşidi görülür ${ }^{90}$ (Resim 29).

89 Abubakir Divayev, "Volshebnyi zagovor protiv ukusa yadovitı nasekomıh i presmikaushihsya", Turkestanskiye Vedomosti, 7 (1893), s. 32-33.

90 Sergei Tolstov,"Goroda guzov", Sovetskaya etnografiya 3 (1947), s. 66-68; Tolstov, Po sledam..., s. 210; Tolstov, Po drevnim..., s. 199. 


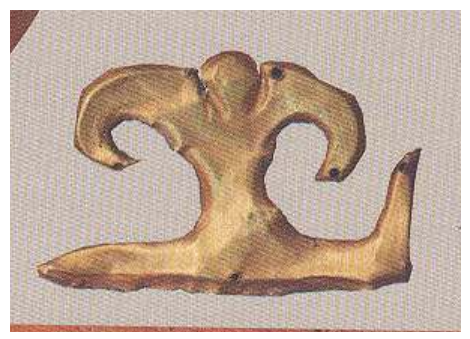

a

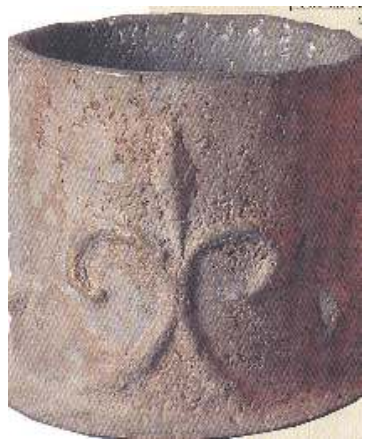

c

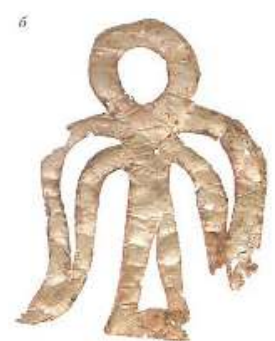

b

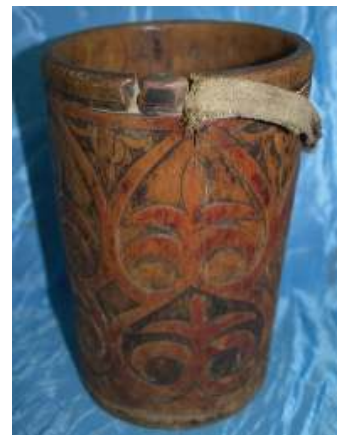

d

Resim 29: a, b. İnsan suretli (antromorfik) bir tür düğme şekli; c. Tulğamüyüz (boynuzlu insan) şekli verilmiş tunç mumluk. Orta asırlık Otırar şehri. $11-12$ yy:; ${ }^{91}$ d. Kese kap. Tulgamüyüz. Kızılorda, Şiyeli müzesi kolleksiyonundan.

Koç boynuzu, bütün el işi eşyalarda yer alır. Bununla birlikte, çoğalmanın, nesli devam ettirmenin işareti olarak büyük sihirli bir ritüel anlama da sahiptir. Türk soylu Türk, Kırgız, Türkmen, Azerbaycan halkları arasında çok yaygındır. Koç boynuzunun Sinarmüyüz (yarım boynuz), Sinımüyüz (kırık boynuz) adlı türleri boynuzun bir yarısına benzerdir ve genelde kilimlerin kenarlarına nakşedilmiştir. Kanatti koşkarmüyüz (kanatlı koç boynuzu), Koskoşkar müyüz (çift koç boynuzu) nakışlarında boynuz kıvrılarak sona eriyor. Karmaşıklığı göz önüne alındığında bu nakışlar kilim, keçe döşeme ve halılara işlenmiştir. Koç boynuzunun Tulğamüyüz (boynuzlu insan) olarak adlandırılan insan şeklini ortaya koyan antromorfik nakış şekli ve Törtkulak (dört kulak) diye adlandırılan dört köşesine döndürerek şekillendirilmiş türü de kilim ve keçe döşemelere nakşedilir. Birçok dokuma ürünlerine tumar (muska) koç boynuzu ile beraber taytuyak adlı şekil resmedilir (Resim 30 - 31).

91 Resim 29 a, b, c -Arheologiva Kazahstana, age., s. 218; d - Yazarlara ait fotoğraftur. 


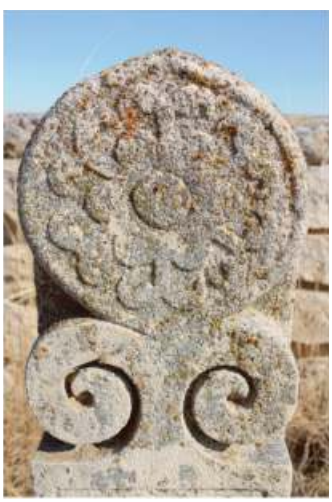

a

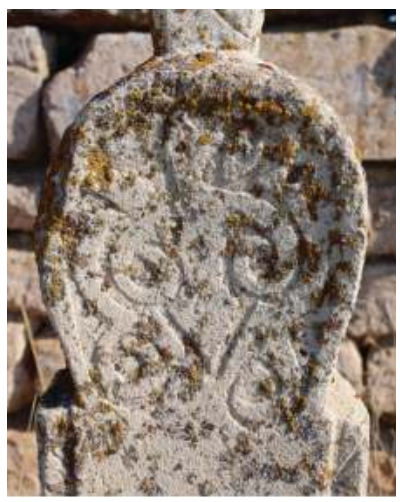

b

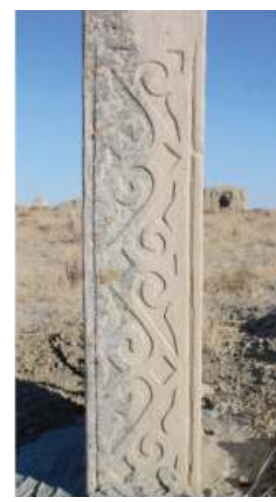

c

Resim 30: Mezar taşlarındaki koç boynuzu: a-b. Tulğamüyüz, Izenagaş mezari; c. Kanatlı koç boynuzu, Taskabak, Doniztau ${ }^{92}$

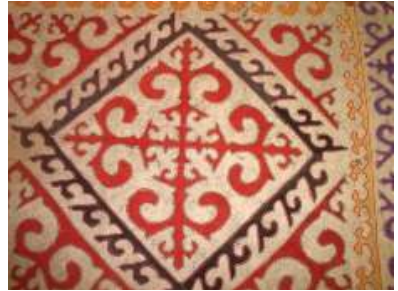

$\mathbf{a}$

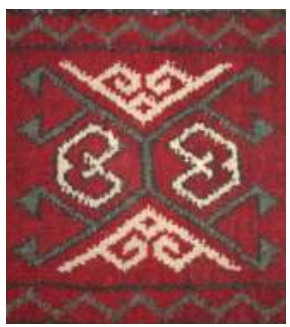

c

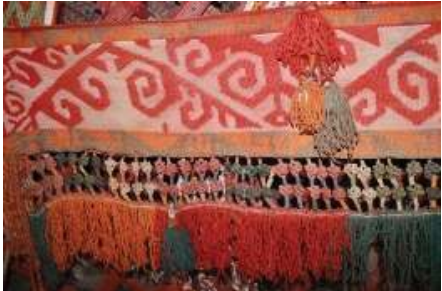

b

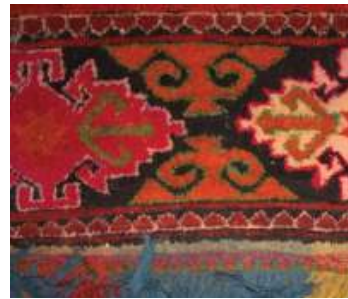

d

Resim 31: a. Törtkulak (dört kulak) koç boynuzu. Sırmak (keçe döşeme) parçası;

b. Keçe çadırın içini çepeçevre süslemiş olan saçaklı baskuradlı süsleme parçaları; c. Tüylü kilim parçası: Tumar koşkarmüyüz ve taytuyak; d. Tüylü kilim parçası: Tulğamüyüz ${ }^{93}$

92 Resim 30 - Yazarlara ait fotoğraftur.

93 Resim 31 - Yazarlara ait fotoğraftır. 
Anadolu Türklerinin halk el sanatları örneklerinde koç boynuzu motifi izleri, somut olmayan kültürel mirasta önemli bir yere sahip olanhalıcılıkta açıkça görülebilmektedir. ${ }^{94}$ Anadolu Türklerinin seramiğge işlenen desenleri ile Kazakların Tumar Koçmüyüz, Törtkulak, Tulğamüyüz, Sinarmüyüz, Sinıkmüyüz desenleri arasında baı farklılıkların da bulunduğu görülmeklebirlikte birçok benzerliğin bulunmas1, Türk soylu halkların ortak etnik kökene ait olmasıyla alakalıdır (Resim 32) ${ }^{95} \mathrm{Bu}$ farklılıklardan bazıları aşağıda verilen Anadolu kilim örneklerinde açıkça görülmektedir. Türkiye kilimlerinde daha çok geometrik şekiller ağır basmakta, Kazak örneklerde ise hayvan motifleri öne çıkmaktadır. Hayvan motiflerinin Türkmen Türklerinde de ağırlık bastığı söylenebilir. ${ }^{96}$

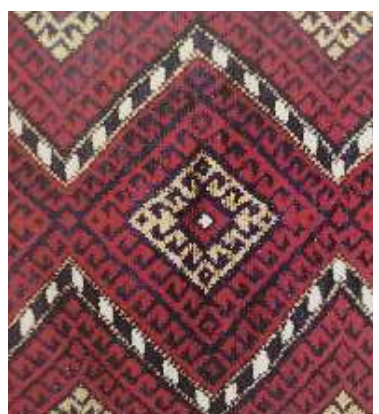

a

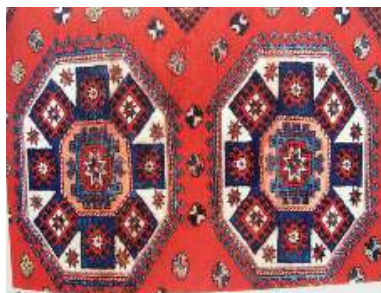

c

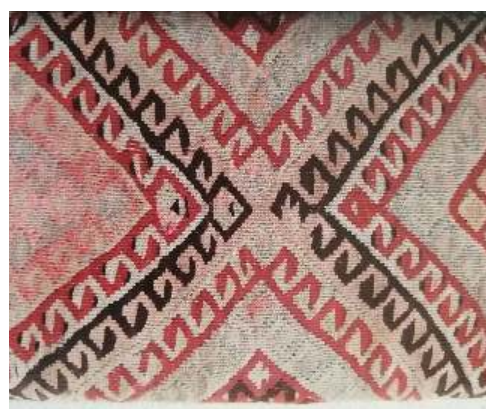

b

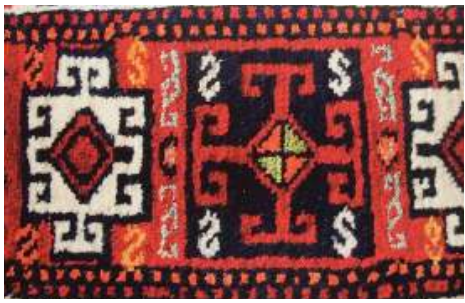

d

Resim 32: a. Balikeser, Türkiye kilimi parçası; b. Tunceli, Türkiye yastık kilimi parçası; c. Ezine-Çanakkale, Türkiye kilimi parçası; d. Tunceli Türkiye yastık kilimi parçası. ${ }^{97}$

Öcal Oğuz, vd., Ankara'nnn Somut Olmayan Kültuirel Mirasi, Kalkınma Ajansı, Ankara 2012, s. $212-$ 214.; Öcal Oğuz, Somut Somut Olmayan Kültürel Miras nedir?, Geneleksel Yayıncllı, Ankara 2018, s. 143-151.

95 Çoruhlu, age., s. 93.

96 Elmira Mecidova, vd., Turkmen Folk Art, Aşhabat, Türkmenistan, 1990. s. 280-290.

97 Mustafa Aksoy, age., Resim 32a - s. 289; b - s. 288; c - s. 233; d-s. 224. 
Süsleme kompozisyonunun en zengin örneklerinden birinin halı olduğu bilinmektedir.2010 yllında Azerbaycan Türklerinin halı dokuma sanatı UNESCO'nun somut olmayan kültürel mirası listesine dahil edilmiştir.Azerbaycan halıları dokuma süslemelerinin örgü özelliklerine bağlı olarak Şirvan, Karabağ, Kuba, Baki, Kazah, Tebriz okullarına ayrılmışır. Kuba okulunun halılarındaki süslemelerin büyük bir kısmı, Türk halklarının koç boynuzu süslemelerine benzer. Törtkulak, Sinarmüyüz, Sinkmüyüz desenleri Azerbaycanlı dokumacılar tarafindan dokunan halılarda da görülebilmektedir (Resim 33). ${ }^{98}$

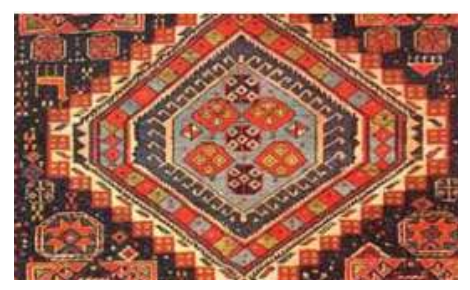

a

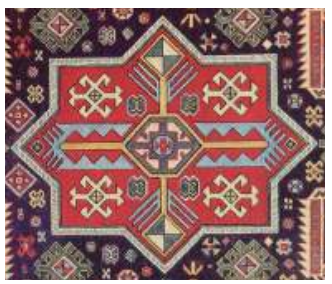

b

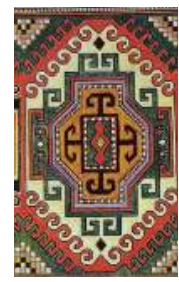

c

Resim 33: Azerbaycan kilimi parçaları ${ }^{99}$

Azerbaycan halılarında, ön ve Orta Asya Türklerinin etnokültürel bağ unsurları açıkça görülebilmektedir. Azerbaycan halk biliminde, ortaçağdan kalma, Orta Asya ve Doğu Asya'dan gelen desenlerin zoomorfik temelleri, İslam'dan önceki kökleri dikkat çekmektedir. Bu desenlerin 10. ve 13. yüzyıllar aralığında yerel halk kültürüyle bütünleştiğive daha sonra yüzyıldan yüzyıla dönüşüme uğradığı görünmektedir. ${ }^{100}$

Vefat etmiş rahmetlinin başucuna konulan mezar taşları ile anıtların üzerinde keskilenmiş koç boynuzu nakışının sık görünmesi, ardında kalan nesillerin atababalarının kültlerine tapınmaları, ata-baba ruhundan medet umup, sağ salim yaşayabilmeleri için yardım istemeleriyle alakalıdır.

Mısır'daki Memlüklerin yönetimini 1260 ylı Berişs soyundan çıan Sultan Baybars'ın aldığı tarihten bellidir. Baybars vefat ettikten sonra 1279 ylı Şerkeş soyundan olan Kalayın Sultan yönetime geçmiştir. O bir zamanlar Baybars'ın yaptırttı̆̆ı El-Azhar camisinin kapısını koç boynuzu şekliyle süslettirir. Böylece, kendisinin

98 Azərbaycan xalçalari. http://www.history.az/Xalchachiliq/ (Erişim Tarihi: 04.07. 2020)

99 Resim 33 a - Azərbaycan xalçalari. http://www.history.az/Xalchachiliq/ (Erişim Tarihi: 04.07. 2020); b,c - Mustafa Aksoy, age., s. 223, 270.

100 Roya Tagiyeva, Azerbaycanskii kover: proishojdeniye I simvolika, Kovri Azerbaycana, 2(2015), s. 27. 
Türk soyundan olduğunu ilan ediyor. Koç boynuzu dengeyi de bildirir. Çünkü koçun yaradılışından iki boynuzu eşittir. Kazak topraklarını eskiden mekan eden insanlar bu nakışı tabiattan aldığı aşikardır.

Kanatlı koç boynuzlu nakışı arkarmüyüz (dağ koyunu boynuzu) diye de adlandırirlar.

Günümüzde kullanılan koç boynuzu nakışlarının bütün türleri, eski devirlerden günümüze hiç değişmeden ulaşmıştır.

\section{Sonuç}

Kazak halkının dünya görüşündeki koyun, koç kültü asırlarca yaşayarak, millî özellikleri zenginleştirerek belirginleştirmektedir. Geleneksel Kazak toplumunda halkın rahat ettiği döneme "koy üstüne boztorğay jumırtkalağan zaman" (koyunun üzerine kuşun yumurtladığı bir dönem), yani huzurun ve barışın hâkim olduğu bir zaman demişlerdir. Kazak halkı koyunu sadece dört tülük hayvanın biri olarak görmeyip, gelenek görenek sisteminde de genişçe yer verip, eskiden bu yana süregelmekte olan büyülü ve sembolik anlamlarına çok önem vermişlerdir. Baksılar ile halk hekimleri hastalığı taşıma yöntemiyle insanları hastalıklardan kurtarmıştır, koyunu kurban ederek çeşitli tehilikelere karşı önlem almışlardır. İslam dönemine kadar kurbanlık hayvan yılkı olmuşsa İslam döneminden sonra kurbanlık hayvan tipi gökyüzünden inmiş kök koşkar, yani koç görüntüsüne dönüşmüştür.

Kazak halkı için koyun bu güne kadar sadece kurbanlık hayvan olarak değil, kaburgaları süsleme ve uygulamalı sanat eserlerinde, kürek kemiği, incik kemiği, boyun omurgası, baş kemiği, yününün özellikleri dilekleri gerekleştirmek uğrunda sihirli bir rol oynamıştr. Koyun, esas geçim ve gelir kaynağı oldu. Koyunun yapağı yününü satışa çıkartmışlardır, güzün kırkılan yününü ev ihtiyaçlarına, keçe hazırlamaya, dokumacılığa kullanmışlardır. Koyun, koç bir şeyin değeri ve para karşıllğ̣ olarak da geçerli olmuştur. Kazak gelenek görenekelerinde erkek kişinin değeri 1000 koyun, kadının değeriise 500 koyun olarak biçilmiştir. Koyun ile koç gelin olarak alınan kız için ödenen başlık olarak da geçmiştir. "Dede Korkut" destanındaki "Bamsı Beyrek Hikayesinde" Deli Karçar kız kardeşi Banı Çiçek'e başlğ̆in başka türleriyle birlikte 1000 koç istemiştir. Kazaklar arasında günümüzde de kız evlendirme düğünlerinde damadın ana babası başlıtan ayrıca, "ölü dirisine" yani ölmüşlerin ruhları şad olsun diye 1 koyun götürürler. Kızı doğum yaptığında kızın ana babası kaljası (yenidoğum yapan kadın için kesilen hayvan) diye 1 koyun verirler. Koyun para yerine geçen değiş tokuş aracı da olmuştur. Göçebe Kazaklar 
tüccarlardan beğendikleri eşyaları koyun derisine, yününe değiştirmişlerdir. Kazaklarda "koyunsuz evin değeri yok, kızsız evin güzellĭgi yok" diye bir atasözü de vardır. Eski göçebelerin kosmogonik konseptine göre koç ve dağ koyunu diğer dünya ile insanın yaşam alanını birbirine bağlayan aracı (medyatör) işlevini görmüş̧ür. Petrogliflerdeki güneş ile koç, dağ koyunu şekillerinin yanyana resmedilmiş motifleri, zaman zaman güneşle bile eşit görüldüğünü kanıtlamaktadır. Koç şeklinin mutuluk ve refah fikrini taşıması, mutluluk ve refah sembolü olarak Kazak halkının dünya görüşünde sağlambir şekilde yerleşmiştir. Bu, çok eski dönemlerden oluşup, nesilden nesile sürdürülmekte olan gelenekle alakalıdır. Koşkarmüyüz (koç boynuzu) nakışının Kazakistan’ın Devlet bayrağında yer alması bile, koç boynuzunun Kazak halkının ulusal markası olduğunu kanıtlamaktadır.

\section{KAYNAKLAR}

Agadjanov, Sergei, Oçerki istorii oguzov i turkmen Srednei Azii IX-XIII vv. Aşhabad: Ylym,1969.

Ahinjanov, Serjan, K voprosu o znakah na keramike pozdnesrednevekovogo Otrara, V knige: Drevnosti Kazahstana, Almaty 1975.

Ahinjanov, Serjan, Iz istorii dvizheniya kochevyh plemen avraziiskih stepei v pervoi polovine XI veka. V knige: Arheologicheskie issledovaniya drevnego i srednevekovogo Kazakhstana, Gylym, Almaty 1980.

Akişev, Kemal - Baypakov, Karl - Erzakovich, Lev., Drevnii Otrar, Gylym, Almaty 1972.

Akişev, Kemal - Akişev, Alisher. Proishozhdenie i semantika Issykskogo golornogo ubora.V knige: Arheologicheskie issledovaniya drevnego i srednevekovogo Kazahstana, Gylym, Almaty 1980, s. 14-31.

Aksoy, Mustafa, Tunceli'de Koç-Koyun Heykelleri ve Balballar http://www.mustafaaksoy.com/makale-114-Tunceli-de-Koc-Koyun-Heykelleri-ve-Balballar (Erişim Tarihi: 30.11.2016).

Aksoy, Mustafa, Kazakistan'da Koç - Koyun Heykelli Mezar Taşlan. http://www.mustafaaksoy.com/dosyalar/Kazakistan-da-Koc-Koyun-Heykelli-Mezarlar.pdf (Erişim Tarihi: 29.11.2016).

Aksoy, Mustafa, Tarihin Sessiz Dili Damgalar, İstanbul 2014. 
Alekperli, Farid, "Zoomorfnye memorial'nye pamjatniki Azerbaidjana". Tezisy III Mezhdunarodnoi nauchnoi konferencii "Turkologicheskoe Iskusstvoznanie: Problemy i Perspektivy", Baku 2013, s. 30-36.

Alimbay, Nursan vd., Kazaktyn etnografiyalyk kategoriyalar, ugymdar men ataularynyn destyrli zhuiesi, 3 tom, Adam DamuIntegrasiya, Almaty 2017.

Argynbayev, Halel, "Narodnye obichai i pover'ya kazahov, sviazannye so skotovodstvom". V knige: Hoziaistvenno-kul'turnye tradicii narodov Srednei Azii i Kazahstana, Nauka, Moskva 1975, s. 194-205.

Arheologicheskaya otkrytiya 2007 goda, Litres, Moskva 2014.

Arheologiya Kazahstana, Oner, Almaty 2006.

Ajiğali, Serik, Kratel elinin asyl murasy: koshpendi Aral-Kaspï onirinin tarihy men madenieti turaly, TimasPrinthause, Almaty 2006.

Azərbaycan xalçalari. http://www.history.az/Xalchachiliq/ (Erişim Tarihi: 04.07. 2020)

Baypakov, Karl, “Kul't barana u Syrdar'inskih plemen”. V knige: Arheologicheskie issledovanïa drevnego i srednevekovogo Kazahstana, Gylym, Almaty 1980.

Başmanov, Alexandr, "Pervobytnaya istoriya turecko-mongol'skih plemen”, Turkestanskiye vedomosti, 49 (1914), s. 4-5.

Berkli, Yunus, "Erzurum'da Yeni Bulunan Haç Motifli Koç Heykelinin Düşündürdükleri”. A.Ü. Türkiyat Araştırmalan Enstitüsü Dergisi, 34 (2007), s. 215-232.

Bernştam, Alexandr, Istoriko-arheologicheskie ocherki Central'nogo Tiyan'-Shaniya i PamiroAlaya. Materialy i issledovaniya po arheologii SSSR. Vyp 26, Moskva 1952.

Çoruhlu, Yaşar, Türk mitolojisinin ana hatlar, Kabalcı Yayınevi, İstanbul 2000.

Çoruhlu, Yaşar, “Türk Sanatı'nda Koyun, Koç, Keçi Figürlerinin Sembolizmi”. Türk Dünyası Tarih Dergisi, 100 (Nisan 1995), s. 52-60.

Çoruhlu, Yaşar, "At ve Koç/Koyun Şekilli Mezar Taşlarının Sembolizmi”. Toplumsal Tarih, 94 (2000), s. 35-42.

Dalkesen, Nilgün, “Orta Asya'dan Anadolu'ya Türk Kültüründe Geyik Kültü”. Millî Folklor, 106 (2015), s. 58-69.

Danık, Ertuğrul, Koç ve at şeklindeki Tunceli Mezar Taşlar, Ankara 1990. 
Danık, Ertuğrul, "Koç ve at şeklindeki Anadolu mesar taşlarinin dağilimi”, Türk Arkeoloji ve Etnografya Dergisi, 4 (2004), s. 19-28. http://www.kulturvarliklari. gov.tr/sempozyum_pdf/dergi/turk.ark.etn.derg.4.pdf (Erişim Tarihi: 30.11. 2016).

Demirci, Hikmet - Bürkütbayeva, Şınaray, "Kazak Misafirperverliği: Ülüş, Misafir Ağirlama ve Tabak Kültürü” Milli Folklor, 126 (2020), s. 198-209.

Divayev, Abubakir, "Kirgizskie bolezni i sposoby ih lecheniya", Turkestanskive vedomosti, 80 (1902), s. 482; 43 (1903), s. 263.

Divayev, Abubakir, "Volshebnyi zagovor protiv ukusa yadovith nasekomih i presmikaushihsya", Turkestanskiye vedomosti, 7 (1893), s. 32-33.

Divayev, Abubakir, "Pastuhi". Turkestanskiye vedomosti, 4 (1905), s. 14.

Divayev, Abubakir, Tartu, Ana tili, Almaty 1992.

Diykanbayeva, Mayramgül, "Kirgizlarda “Tört Tülük” Hayvanla İlgili İnanış ve Uygulamalar", Milli Folklor, 115 (2017), s. 133-140.

Gülensoy, Tuncer, Orhun'dan Anadolu'ya Türk Damgaları. Istanbul, 1989 http:// gobustan.cls.az/front/files/libraries/1665/books/927675584.pdf (Erişim Tarihi: 01.07.2020).

Gumilev, Lef, Sosedi hazar, Litres, Moskva 2004.

Griaznov, Mihail, Pervyi Pazyrykskii kurgan, Ripol Klassik, Moskva 2013.

Kalafat, Yaşar, Kars’ta Gregoryen türkler ve mezar mimarileri - Ak ve Kara Koyunlu Mezar Taşlarının Çizdiği Tarihî-Coğrafî Kültürün Sınırları. http://www.yasarkalafat.info/kalafat.info/dosyalar/kalafat2014151920.pdf (Erişim Tarihi: 27.11.2016).

Karuts, Rihard, Sredikirgizov i turkmenov na Mangishlake, (Çev. E. Petri), Tipografiya A.F. Devriyeva, Sankt-Peterburg 1911.

Kastaniye, Iosif, Nadgrobnye sooruzhenija kirgizskih stepei, Tipografiya Turgaiskogo Oblastnogo upravleniya, Orenburg 1911.

Kastaniye, Iosif, Poezdka po Turgaiskoi i Syr-Darinskoi oblasti. 1906 - 1907 g. Vdol' Taskentskoi zheleznoi dorogi, Tipografiya G.M. Mil’berg, Orenburg 1909.

Kastaniye, Iosif, Iz oblasti kirgizskih verovaniyi. Vestnik Orenburskogo Uchebnogo Okruga.1, 
3 (1912), s. 71-93; 4 (1913), s. 112-124; 5, s. 149-166, s. 201-218; 6, s. 187196.

Komarov, Petr, "Poveriya kirgizov", Turkestanskiye vedomosti, 150 (1905), s. 790.

"Korkyt Ata” Enciklopedialuk jinak, Kazak enciklopediasy, Almaty 1999.

Kratkoe soobshheniya o dokladah $i$ polevy issledovaniyah Instituta istorii material'noj kul'tury. 5 yyp, Izdatel'stvo Akademi Nauk SSSR, Moskva 2007.

Levina, Ludmila, Keramika nizhnei i srednei Syrdar’i v I tysiyacheletii n.e., Nauka, Moskva 1971.

Levina, Ludmila, Puteshestvie po Turkestanu N.Severcova i A.Fedchenko, Izdanie A.F. Devrieva, Sankt-Peterburg 1894.

Mecidova, Elmira, vd., Turkmen Folk Art. Aşhabat, Türkmenistan 1990.

Nurimanov, Bekarys - Altay, Amanzhol, “Karacaoğlan ve Bukar Kalkamanuli’nin şiirlerinin karşilaştirilmasi”, Milli Folklor, 117 (2018), s. 41-56.

Oğuz, Öcal, vd., Ankara’nin Somut Olmayan Kültürel Mirasi, Kalkınma Ajansı, Ankara 2012.

Oğuz, Öcal, Somut Somut Olmayan Kültürel Miras nedir?, Geneleksel Yayıncılık, Ankara 2018.

Özdemir, Ali Rıza, Koç Heykelli Mezarlarn İzinde: Zazalarve Türklük, Kripto Yayınları, Ankara 2010.

Pallas, Petr Simon, Puteshestviye po raznım provintsiyam Rossiskoy imperiyi. P.1. Putishestviye 1768-1769 y.y. Translation of O. Tomsky, Tipog. Imp. ASc, Sankt-Peterburg 1773.

Paşino, Petr, Turkestanskii krai v 1866 godu, Putevne zametki, Sankt-Peterburg 1868.

Plano Karpini i Gil'oma de Rubruk, Puteshestviya v vostochnye strany, Gylym, Almaty 1993.

Polos'mak, Nataliya, Vsadniki Ukoka, Infolio-press, Novosibirsk 2001.

Poltaraskaya, Lubov, "Obychai kirgizov Semipalatinskoi oblasti”, Russkii vestnik, 9 (1878), s. 22-69.

Potanin, Grigori, Ocherki Severo-ZapadnoiMongolii, Vyp II. Materialyi etnograficheskie, Sankt-Peterburg 1881. 
Renato, Sala - Jan-Mark, Deom, Naskalniye izobrajeniye Yezhnogo Kazakhistana, Almaty: Geoarkheologiya 2005.

Samaşev, Zeinulla - Kuşerbaev, Krymbek - Amanşaev, Ermek - Astaf'ev Andrei, Sokrovishha Ustiurta i Mankystau, Arheologiya, Almaty 2007.

Simakov, Gennadi, Obșesțennye funksii kirgizskih narodnyh razvlecçenii v konse 19 - naçale 20 v. Nauka, Leningrad 1984.

Snesarev, Gleb, Relikty domusul'manskih verovanij i obrjadov u uzbekov Horezma, Moskva 1969.

Tagiyeva, Roya, Azerbaycanskii kover: proishojdeniye I simvolika, Kovri Azerbaycana. 2(2015), s. 26-30.

Toleubayev, Abdeş, Relikty doislamskih verovanii v semeinoi obriadnosti kazahov (XIXnach. XX vo.) Gylym, Almaty 1991.

Tolstov, Sergei, "Goroda guzov", Sovetskaya etnografiya. 3 (1947), s. 55-102.

Tolstov, Sergei, Po sledam drevnehorezomskoi civilizacii, Izdatelstvo Akademii Nauk SSSR, Moskva 1948.

Tolstov, Sergei, Drevnii Horezm, Opyt istoriko-arkeologiçeskogo issledovanija, Izdanie MGU, Moskva 1948a.

Tolstov, Sergei, Po drevnim del'tam Oksa i Jaksarta, Izdatel'stvo Vostoçnoi literatury, Moskva 1962.

Vaynberg, Bella, Monety drevnego Horezma, Nauka, Moskva 1977.

Valihanov, Çokan. Sobraniye sochineniyi v pyati tomah. Volume 4. Almaty: Glavnaya redaksiya Kazahskoy sovetskoy ensiklopediyi, 1985.

Vişnevskaya, Olga, Kul'tura sakskih plemen nizov'ev Syrdar'i v VII-V vo. do n. e. po materialam Uigaraka, Nauka, Moskva 1973.

Zalesskii, Bronislav, Kazak saharasina sayahat, Oner, Almaty 1991.

Zavituhina, Marya, Kurgannyi mogil’nik Srostki 2 na Altae. Soobşhenie Gosudarstvennogo Jermitazha, Vyp 27, Sankt-Peterburg 1963. 
